\title{
Finding of Ca. 1.6 Ga Detrital Zircons from the Mesoproterozoic Dagushi Group, Northern Margin of the Yangtze Block
}

\author{
Xiaofeng Xie ${ }^{1,2}$, Zhenning Yang ${ }^{1,3,4, *}$, Huan Zhang ${ }^{1,5}$, Ali Polat ${ }^{6,7}$, Yang $\mathrm{Xu}^{1}$ and Xin Deng ${ }^{1}$ \\ 1 School of Earth Sciences, China University of Geosciences Wuhan, Wuhan 430074, China; \\ jiansheng2865@126.com (X.X.); huanxiaozhangde@163.com (H.Z.); xuyang_0112@163.com (Y.X.); \\ cugxd@163.com (X.D.) \\ 2 Geological Party 103, Guizhou Bureau of Geology \& Mineral Exploration and Development, Tongren 554300, China \\ 3 Hebei Key Laboratory of Strategic Critical Mineral Resources, Hebei GEO University, Shijiazhuang 050031, China \\ 4 College of Earth Sciences, Hebei GEO University, Shijiazhuang 050031, China \\ 5 The Second Geo-Exploration Institute of Mineral Prospecting and Development Bureau of Henan Province, \\ Zhengzhou 450000, China \\ 6 School of the Environment, University of Windsor, Windsor, ON N9B 3P4, Canada; polat@uwindsor.ca \\ 7 Center for Global Tectonics, Faculty of Earth Sciences, China University of Geosciences Wuhan, \\ Wuhan 430074, China \\ * Correspondence: znyang@hgu.edu.cn; Tel.: +86-311-8720-8285
}

Citation: Xie, X.; Yang, Z.; Zhang, H.; Polat, A.; Xu, Y.; Deng, X. Finding of Ca. 1.6 Ga Detrital Zircons from the Mesoproterozoic Dagushi Group, Northern Margin of the Yangtze Block. Minerals 2021, 11, 371. https://doi.org/10.3390/min11040371

Academic Editor:

Rubén Díez-Fernández

Received: 5 February 2021

Accepted: 29 March 2021

Published: 31 March 2021

Publisher's Note: MDPI stays neutral with regard to jurisdictional claims in published maps and institutional affiliations.

Copyright: () 2021 by the authors. Licensee MDPI, Basel, Switzerland. This article is an open access article distributed under the terms and conditions of the Creative Commons Attribution (CC BY) license (https:// creativecommons.org/licenses/by/ $4.0 /)$.

\begin{abstract}
The middle Mesoproterozoic is a crucial time period for understanding the Precambrian tectonic evolutionary history of the northern Yangtze Block and its relationship with the supercontinent Columbia. The Dagushi Group (Gp) is one of the Mesoproterozoic strata rarely found at the northern margin of the Yangtze Block. U-Pb geochronology and Lu-Hf isotopic analyses of detrital zircons were analyzed for three metamorphic quartz sandstone samples collected from the Luohanling and Dangpuling formations of the Dagushi Gp. These metasandstones yielded major zircon populations at $\sim 2.65 \mathrm{Ga}$ and $\sim 1.60 \mathrm{Ga}$, respectively. The $\sim 1.60 \mathrm{Ga}$ ages first discovered yield a narrow range of $\epsilon \mathrm{Hf}_{(\mathrm{t})}$ values from -1.8 to +1.8 , which lie above the old crust evolutionary line of the Yangtze Block, suggesting the addition of mantle material. Trace element data indicate that $\sim 1.60 \mathrm{Ga}$ detrital zircons share a basic provenance, whereby they have low Hf/Th and high $\mathrm{Nb} / \mathrm{Yb}$ ratios. Zircon discrimination diagrams suggest that the $\sim 1.60 \mathrm{Ga}$ detrital zircon source rocks formed in an intra-plate rifting environment. Dagushi Gp provenance studies indicate that the $\sim 1.60 \mathrm{Ga}$ detrital zircon was most likely sourced from the interior Yangtze Block. Thus, we suggest that the late Paleoproterozoic to early Mesoproterozoic continental break-up occurred at the northern margin of the Yangtze Block.
\end{abstract}

Keywords: 1.60 Ga; detrital zircon; Dagushi Group; Yangtze Block; Columbia supercontinent

\section{Introduction}

When compared with the supercontinents Pangea and Rodinia, the architecture of the supercontinent Columbia is ambiguous due to the lack of sufficient and reliable geological and paleomagnetic data [1-5]. There is a broad agreement that the fragmentation of Columbia commenced at ca. $1.60 \mathrm{Ga}$ and formed a number of continental rift zones along the western margin of Laurentia [6,7], as marked by widespread 1.60-1.20 Ga continental rifting, anorogenic magmatism, and emplacement of mafic dyke swarms in almost all cratonic building blocks [1,4,8]. The scarcity of $\sim 1.60-1.50$ Ga zircon sources worldwide [9] makes detrital zircons within this age range particularly useful for constraining the tectonic affinity between different continents.

Many 1.75-1.50 Ga magmatic events in the southwestern Yangtze Block margin were reported in recent studies [8,10-12], and the contemporaneous rift strata were formed, including the Dongchuan, Hekou, and Dahongshan groups [13-16], which were interpreted to be linked to the break-up of the Columbia supercontinent. However, this geological event 
has been rarely identified at the northern margin of the Yangtze Block. Previous studies have shown that the Shennongjia and Dagushi groups have undergone similar crustal evolution, and they are coeval successions deposited in similar environments [17-20]. Detrital zircon $\mathrm{U}-\mathrm{Pb}$ ages and $\mathrm{Lu}-\mathrm{Hf}$ isotopic compositions of the Shennongjia Gp were analyzed recently [18,21-23]. Xiao [18] first identified $~ 1.6 \mathrm{Ga}$ detrital zircon from the Shennongjia Gp and contended that this time period corresponded to the breakup of the Yangtze Block from the Columbia supercontinent.

In this study, we report a new set of zircon $\mathrm{U}-\mathrm{Pb}$ ages and Hf isotopic data for three meta-quartz sandstones from the Dagushi $\mathrm{Gp}$. Combined with previous studies, our results shed new light on the regional tectonic evolution of the northern part of the Yangtze Block during the Late Paleo- to Mesoproterozoic, and they constrain a possible kinship between the Yangtze Block and the Columbia supercontinent.

\section{Geological Setting}

The Yangtze Block is sutured with the North China Craton along the Qinling-DabieSulu orogenic belt to the north in the Triassic, which collided with the Cathaysia Block to the southeast in the early Neoproterozoic along the Sibao (or Jiangnan) orogeny (Figure 1a; [24]). The Kongling terrane is located at the northwestern part of the Yangtze Block (Figure 1a), which is exposed as a small dome of $360 \mathrm{~km}^{2}$ and was intruded by the Paleoproterozoic Quanqitan granite and the huge Neoproterozoic Huangling complex (see [25] and references therein). There are three types of rock associations in this terrane: (1) dioritic, tonalitic, trondhjemitic, and granitic gneisses of intrusive origin (ca. 2.86-2.95 Ga), (2) metasedimentary rocks, and (3) amphibolite and locally preserved mafic granulite (see [25] and references therein). The study area is located in the Dahongshan region in the northern margin of the Yangtze Block, $200 \mathrm{~km}$ east of the Kongling terrane (Figure 1a,b). It is separated from the Tongbai orogen to the north by the Sanligang-Sanyang Fault (Figure 1b) that is part of the east-trending Xiangfan-Guangii Fault.

The Dagushi Gp is the oldest basement exposed in the study area, unconformably overlain by the Huashan Gp, which is in turn overlain by the Nanhua sedimentary units including the Liantuo and Nantuo formations (Figure 1b). Lithologically, the Huashan $\mathrm{Gp}$ is divided into the Hongshansi Formation (Fm) at the bottom and the Liufangzui Fm at the top (Figure 1c) [26]. Recently, Du et al. [27] reported a zircon U-Pb age of $\sim 779 \pm 12 \mathrm{Ma}$ for a tuff layer from the Liantuo Fm. The five youngest zircons from the coarse-grained feldspathic sandstone in the Liufangzui Fm give a weighted average age of $\sim 816 \pm 9 \mathrm{Ma}$ [26], suggesting that initial deposition of the Huashan Gp occurred after ca. $816 \mathrm{Ma}$.

The sedimentary sequences of the Dagushi Gp include, from the bottom up, the Taiyangsi, Hanjiawa, Luohanling, Chenjiachong, Lijiazui, and Dangpuling formations [29]. The Taiyangsi Fm consists of metaconglomerate, meta-pebbly sandstone, medium-coarseto fine-grained metasandstone intercalated with banded slate in the lower part, and metasiltstone and clay slate in the upper section with visible lenticular bedding of sand and gravel [29], pointing to a subaqueous alluvial fan depositional system. Sedimentary characteristics suggest that the water depth increased gradually from the lower to the upper part of the Taiyangsi Fm. The lithological combinations of the Hanjiawa Fm, similar to the Taiyangsi Fm, are mainly slate with a subordinate amount of metasandstone and metaconglomerate. The Luohanling Fm, the most widespread strata of the Dagushi Gp, is composed of siliceous dolomite (Figure 2a), silicolites (Figure 2b), meta-quartz sandstone (Figure 2c), silty-muddy slate (Figure 2d), dolomite (Figure 2e), and various stromatolites. Subhorizontal beddings in this formation are formed in a tidal flat, shallow sea shelf environment. The Chenjiachong Fm contains micro- to fine-crystalline dolomite and stromatolitic dolomite with horizontal bedding. The Lijiazui Fm has silty-muddy slate with limestone lenses. The Dangpuling Fm consists of meta-quartz and meta-feldspar quartz sandstone (Figure 2f,g), with horizontal bedding and cross bedding, which is interpreted to have formed on a littoral shallow-water setting [29]. 

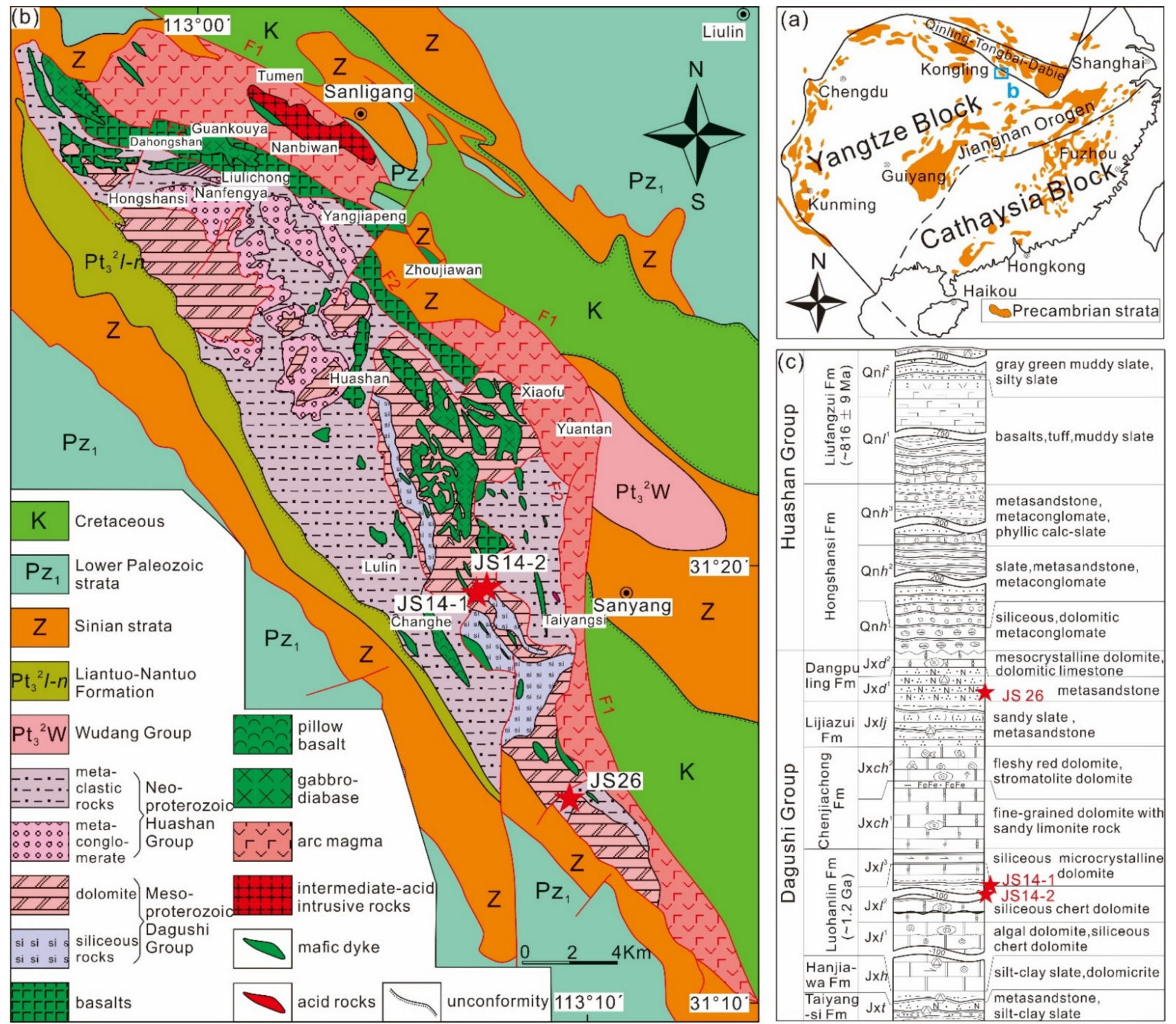

Figure 1. (a) Distribution of Precambrian rocks in the South China Block and the Qinling-Dabie Belt (modified after [24]); (b) simplified geological map of the Dahongshan area (modified after [28]); (c) 1:50,000 geological map of Guchengfan (modified after [29]; ages of the Luohanling Fm and the Liufangzui Fm are from [19,26], respectively); the red stars show the stratigraphic locations of the three metasandstone samples.

Tuff layers from the Luohanling Fm give two zircon $\mathrm{U}-\mathrm{Pb}$ ages of $\sim 1.23 \mathrm{Ga}$ and $\sim 1.24 \mathrm{Ga}$ [19]. The two youngest zircons from the Taiyangsi Fm yield concordant dates of $\sim 919 \pm 10 \mathrm{Ma}$ and $\sim 912 \pm 11 \mathrm{Ma}$ (unpublished data). The youngest zircon date of $\sim 1.12 \mathrm{Ga}$ for the Taiyangsi Fm was provided by [30]. Thus, the depositional ages of the Taiyangsi Fm and the Hanjiawa Fm are constrained to the Neoproterozoic or the latest Mesoproterozoic.

The two medium-coarse-grained meta-quartz sandstone samples (JS14-1 and JS14-2) (Figure 2c), collected from the middle part of Luohanling Fm, are dominated by $>95 \%$ quartz (Figure 2h). The coarse-grained meta-quartz sandstone sample (JS26), collected from the lower part of Dangpuling Fm (Figure 2f), is composed of $95 \%$ quartz and $<3 \%$ lithic clasts (Figure 2i). 

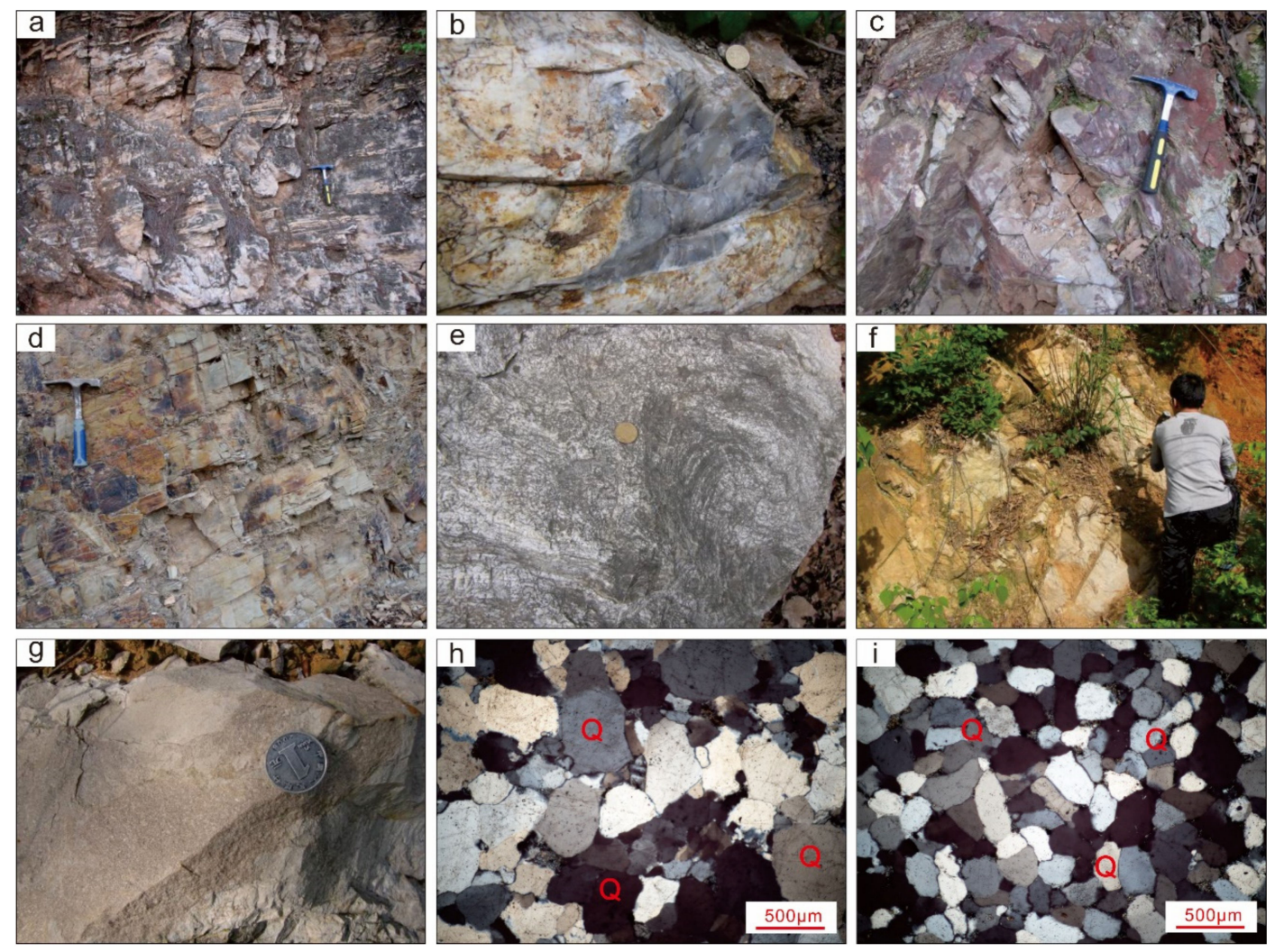

Figure 2. Field photographs (a-g) and photomicrographs (h,i) of the Dagushi Gp. (a) Siliceous dolomite; (b) siliceous-calcite; (c) meta-quartz sandstone; (d) silty-muddy slate; (e) dolomite; (f) meta-quartz sandstone; (g) meta-quartz sandstone; (h) sample JS14-1; and (i) sample JS26; Q: quartz.

\section{Analytical Methods}

\subsection{Zircon $\mathrm{U}-\mathrm{Pb}$ Dating}

Zircons were separated by conventional magnetic and heavy liquid methods and then were selected, according to sizes, colors, shapes, and turbidity under a binocular microscope. The grains were then mounted on double-sided tape, cast in epoxy resin, and polished to expose even and intermediate surfaces. Zircon $\mathrm{U}-\mathrm{Pb}$ dating was conducted by LA-ICP-MS at the State Key Laboratory of Geological Processes and Mineral Resources, China University of Geosciences Wuhan (SKLGPMR-CUG). Laser sampling was performed using a GeoLas 2005 excimer ArF laser-ablation system. An Agilent 7500a ICP-MS instrument was used to acquire ion signal intensities. Standard zircon 91,500 [31] (Table A1, Appendix A) was employed as an external reference material to calibrate isotope fractionation, which was analyzed twice for every five analyses. Standard zircons GJ-1 were analyzed as unknowns [32] (Table A1, Appendix A). Detailed operating conditions for the laser ablation system and the ICP-MS instrument and data processing are the same as described by [33]. The data were analyzed in the ISOPLOT program of Ludwig [34]. Due to lower intensity of the ${ }^{207} \mathrm{~Pb}$ signal, ${ }^{206} \mathrm{~Pb} /{ }^{238} \mathrm{U}$ ages are usually more precise than ${ }^{207} \mathrm{~Pb} /{ }^{235} \mathrm{U}$ and ${ }^{207} \mathrm{~Pb} /{ }^{206} \mathrm{~Pb}$ ages especially for zircons younger than $1.0 \mathrm{Ga}$ [35]. However, ${ }^{207} \mathrm{~Pb} /{ }^{206} \mathrm{~Pb}$ ages are less sensitive to $\mathrm{Pb}$ loss, which is more common in order zircons [36]. Therefore, in most cases, ${ }^{207} \mathrm{~Pb} /{ }^{206} \mathrm{~Pb}$ ages are employed for zircons of age $\geq 1.0 \mathrm{Ga}$ and ${ }^{206} \mathrm{~Pb} /{ }^{238} \mathrm{U}$ ages are employed for zircons of age $<1.0 \mathrm{Ga}$.

\subsection{Zircon Trace Element Analysis}

The trace element analysis was performed simultaneously with the $\mathrm{U}-\mathrm{Pb}$ analysis. Quantitative results for trace elements reported here were obtained through calibration of relative element sensitivities using the NIST-610 standard glass as the external calibration standard [37]. The precision and accuracy of the NIST-610 analyses is presented in Table A2 
(Appendix A). $\mathrm{Nb}$ concentrations of 91,500 obtained in this study fall within the published variation ranges [38].

\subsection{Zircon Lu-Hf Isotope Analysis}

In situ Hf isotope analysis was carried out on a Neptune Plus MC-ICP-MS (Thermo Fisher Scientific, Germany), in combination with the GeoLas 2005 in the SKLGPMR-CUG. Detailed operating conditions for the laser ablation system and the MC-ICP-MS instrument and data calibrating and processing were reported in [39]. We applied the directly obtained $\beta_{\mathrm{Yb}}$ value from the zircon sample itself in real time [40]. The ${ }^{179} \mathrm{Hf} /{ }^{177} \mathrm{Hf}$ and ${ }^{173} \mathrm{Yb} /{ }^{171} \mathrm{Yb}$ ratios were used to calculate the mass bias of $\mathrm{Hf}\left(\beta_{\mathrm{Hf}}\right)$ and $\mathrm{Yb}\left(\beta_{\mathrm{Yb}}\right)$, which were normalized to ${ }^{179} \mathrm{Hf} /{ }^{177} \mathrm{Hf}=0.7325$ [41] and ${ }^{173} \mathrm{Yb} /{ }^{171} \mathrm{Yb}=1.132685$ [42] using an exponential correction for mass bias. Interference of ${ }^{176} \mathrm{Yb}$ on ${ }^{176} \mathrm{Hf}$ was corrected by measuring the interference-free ${ }^{173} \mathrm{Yb}$ isotope and using ${ }^{176} \mathrm{Yb} /{ }^{173} \mathrm{Yb}=0.79639$ to calculate ${ }^{176} \mathrm{Yb} /{ }^{177} \mathrm{Hf}$ [43]. Similarly, the relatively minor interference of ${ }^{176} \mathrm{Lu}$ on ${ }^{176} \mathrm{Hf}$ was corrected by measuring the intensity of the interference-free ${ }^{175} \mathrm{Lu}$ isotope and using the recommended ${ }^{176} \mathrm{Lu} /{ }^{175} \mathrm{Lu}=0.02656$ [44] to calculate ${ }^{176} \mathrm{Lu} /{ }^{177} \mathrm{Hf}$. Time-drift correction was performed using standard zircon 91,500. The interference and mass fractionationcorrected ${ }^{176} \mathrm{Hf} /{ }^{177} \mathrm{Hf}$ ratios of the samples were then calibrated against the standard using the recommended ${ }^{176} \mathrm{Hf} /{ }^{177} \mathrm{Hf}$ ratio of $0.282308 \pm 6(2 \sigma)$ [45] (Table A3, Appendix A). Offline selection and integration of analytic signals, as well as mass bias calibrations, were performed using ICPMSDataCal [40]. To calculate the initial ${ }^{176} \mathrm{Hf} /{ }^{177} \mathrm{Hf}$ ratios, the decay constant of $1.867 \times 10^{-5} \mathrm{Ma}^{-1}$ was used for ${ }^{176} \mathrm{Lu}$ [46]. The $\varepsilon \mathrm{Hf}_{(\mathrm{t})}$ values were calculated with reference to a chondritic uniform reservoir (CHUR). The ${ }^{176} \mathrm{Lu} /{ }^{177} \mathrm{Hf}$ and ${ }^{176} \mathrm{Hf} /{ }^{177} \mathrm{Hf}$ ratios used for the CHUR were 0.0332 and 0.282772 , respectively [44]. The single-stage model age $\left(\mathrm{T}_{\mathrm{DM} 1}\right)$ was calculated relative to a depleted mantle with present-day ${ }^{176} \mathrm{Lu} /{ }^{177} \mathrm{Hf}$ and ${ }^{176} \mathrm{Hf} /{ }^{177} \mathrm{Hf}$ ratios of 0.0384 and 0.28325 , respectively [47]. The two-stage Hf model age $\left(\mathrm{T}_{\mathrm{DM} 2}\right)$, also interpreted as crust formation age, was calculated by projecting the zircon ${ }^{176} \mathrm{Hf} /{ }^{177} \mathrm{Hf}(\mathrm{t})$ back to the depleted-mantle model growth curve, assuming a mean crustal value for $\mathrm{Lu} / \mathrm{Hf}\left({ }^{176} \mathrm{Lu} /{ }^{177} \mathrm{Hf}=0.015\right)$ [48].

\section{Results}

4.1. Zircon Ages and Hf Isotopes

4.1.1. Dangpuling Fm

Sixty zircons were separated from sample JS26 of the Dangpuling Fm (Table A4, Appendix A) and were colorless, transparent, and mostly anhedral, suggesting a longdistance transport. They were 80-150 $\mu \mathrm{m}$ long with length/width ratios of 1.2:1 to 3:1. The majority of zircons showed clear oscillatory or broad zoning (Figure 3). Concentrations of $\mathrm{U}$ and Th were 50-843 ppm and 11-364 ppm, respectively. Th/U ratios ranged from 0.2 to 1.5. A major zircon population occurred in the range of $\sim 2.59-2.69$ Ga defining a strong peak at ca. $2.65 \mathrm{Ga}$ with two small age populations of $\sim 1.90 \mathrm{Ga}$ and $\sim 2.80 \mathrm{Ga}$ (Figure 4 ). The oldest detrital zircon was dated at $\sim 3.00 \mathrm{Ga}$.

\subsubsection{Luohanling Fm}

JS14-1: Seventy-three zircon grains were separated from sample JS14-1 of the Luohanling $\mathrm{Fm}$ and were analyzed for $\mathrm{U}-\mathrm{Pb}$ ages (Table A4, Appendix A). Thirty-three representative dated zircons were selected for the Hf isotope analysis (Table A5, Appendix A). Zircons were colorless, khaki, and anhedral to subhedral. They were 100-200 $\mu \mathrm{m}$ long with length/width ratios of 1.1:1 to 2.5:1. Most zircons showed oscillatory zoning (Figure 3). Concentrations of $U$ and Th were 155-1436 ppm and 78-2674 ppm, respectively. Th/U ratios ranged from 0.2 to 2.2 . The significant $\mathrm{U}-\mathrm{Pb}$ age population was at $\sim 1.45-1.68 \mathrm{Ga}$ with two small age populations of $\sim 1.85-2.23 \mathrm{Ga}$ and $\sim 2.62-2.86 \mathrm{Ga}$, and the dominant peak appeared at ca. $1.60 \mathrm{Ga}$ (Figure 4). 


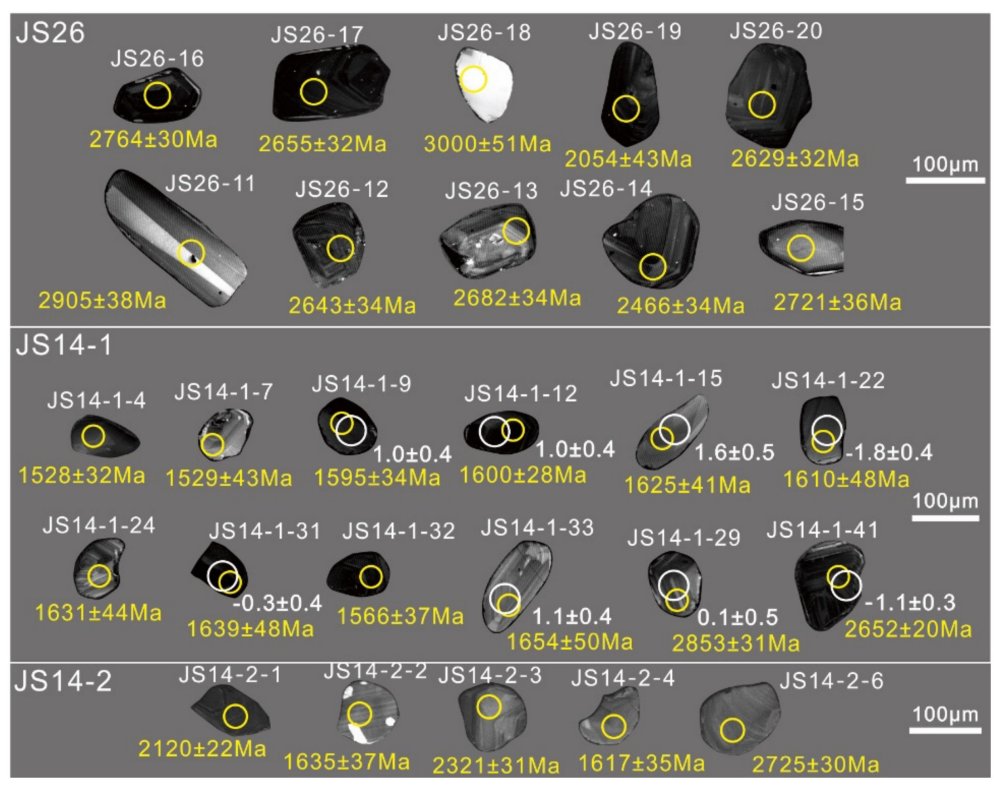

Figure 3. Cathodoluminescence images of zircon grains from three metasandstone samples JS26, JS14-1, and JS14-2. The smaller yellow circles denote the LA-ICP-MS dating spots, whereas the larger white circles the locations of $\mathrm{Lu}-\mathrm{Hf}$ isotope analysis. Zircon $\mathrm{U}-\mathrm{Pb}$ ages and $\varepsilon \mathrm{Hf}_{(\mathrm{t})}$ values together with $1 \sigma$ uncertainties are shown for individual spots.
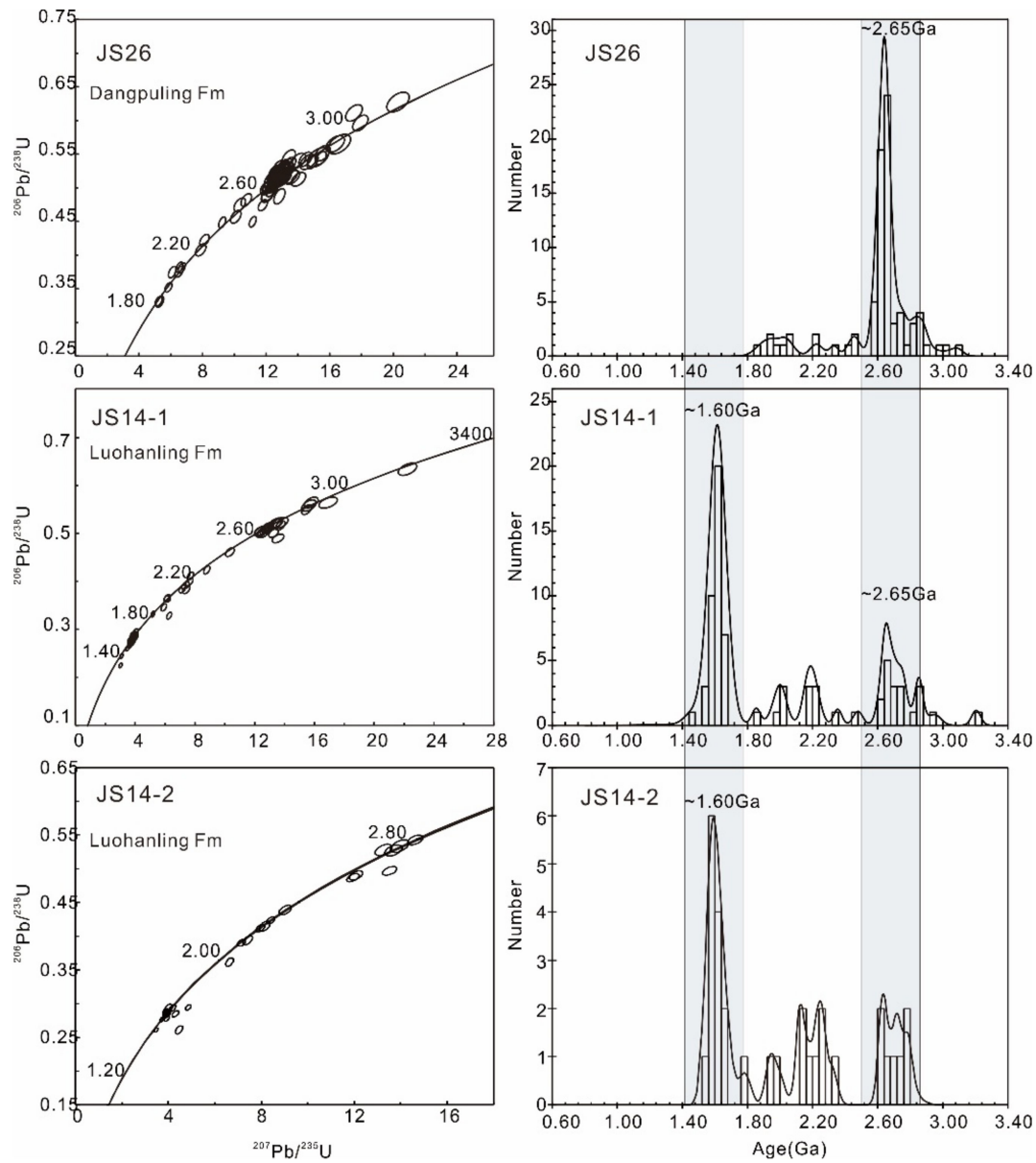

Figure 4. $\mathrm{U}-\mathrm{Pb}$ concordia plots of detrital zircons (left panel) and corresponding relative probability density diagrams of zircon ages (right panel) from the Dagushi Gp. 
Zircon grains for ca. $1.60 \mathrm{Ga}$ had chiefly positive $\varepsilon \mathrm{Hf}_{(\mathrm{t})}$ values and showed a range from -1.8 to +1.8 (Table A5, Appendix A). Paleoproterozoic zircons (ca. $2.65 \mathrm{Ga}$ ) mostly had $\varepsilon \mathrm{Hf}_{(\mathrm{t})}$ values ranging from -1.1 to +1.4 . Three older zircons (ca. $2.85 \mathrm{Ga}$ ) showed variable $\varepsilon \mathrm{Hf}_{(\mathrm{t})}$ values from -0.8 to +0.1 .

JS14-2: Thirty zircon grains were separated from sample JS14-2 from the Luohanling Fm and were analyzed for U-Pb ages (Table A4, Appendix A). The morphological features of detrital zircons were similar to those of sample JS14-1. The major age population was $\sim 1.55-1.68$ Ga with two small age populations of $\sim 1.78-2.32 \mathrm{Ga}$ and $\sim 2.62-2.79 \mathrm{Ga}$, and the major peak was at ca. $1.60 \mathrm{Ga}$ (Figure 4 ).

\section{Discussion}

\subsection{Provenance of the Dagushi Gp}

The detrital zircon ages from the Dagushi Gp in our study yielded two major peaks at $\sim 2.65 \mathrm{Ga}$ and $\sim 1.60 \mathrm{Ga}$ (Figures 4 and $5 \mathrm{a}$ ). The Luohanling Fm had two age peaks ( 1.60 Ga and $\sim 2.65 \mathrm{Ga})$, while the Dangpuling Fm had only one $(\sim 2.65 \mathrm{Ga})$, demonstrating significant discrepancy in the age spectrum among different samples. In addition, Kong et al. [49] reported ages from the Lijiazui and Luohanling formations, which are distinctly different from $\mathrm{U}-\mathrm{Pb}$ ages presented above, reflecting changes in provenance for individual Dagushi Gp samples.

The $\sim 2.65 \mathrm{Ga}$ magmatism is widespread in the northern margin of the Yangtze Block, such as $\sim 2.70-2.60 \mathrm{Ga}$ A-type granitic gneisses [50], 2.66 Ga biotite granites, and $\sim 2.70-2.64$ Ga two-mica granites [51] in the Kongling terrane with $\sim 2.65 \mathrm{Ga}$ A-type granites $[52,53]$ in the Huji area, northern Hubei Province. The oldest rocks exposed in the Kongling terrane are tonalite-trondhjemite-granodiorite (TTG) gneisses that formed in two time intervals: $\sim 3.40-3.20 \mathrm{Ga}$ and $\sim 2.90-2.80$ Ga [54-58], which may offer materials for $\sim 2.80-3.00$ Ga detrital zircons.

A number of $\sim 2.20-1.80$ Ga metamorphic and magmatic events have been identified in the Kongling terrane and its surrounding areas in the northern part of the Yangtze Block [25,59-64]. Two major phases of juvenile crustal growth, 2.20-2.10 Ga in the Kongling terrane and the Tongbai-Dabie orogeny $[65,66]$ and $\sim 1.85$ Ga in the Dabie-Sulu orogeny [65], were also documented. Yang et al. [26] reported abundant $2.00 \mathrm{Ga}$ detrital zircon around the Yangtze Block. Thus, we prefer an interpretation that the $\sim 1.80-2.30 \mathrm{Ga}$ detrital zircons in the Dagushi Gp were predominantly derived from the interior of the Yangtze Block.

Magmatism and metamorphism at ca. 1.60 Ga have not been documented in the northern margin of the Yangtze Block except for the detrital zircon ages obtained from the Shennongjia Gp (Figure 5c) [18]. This episode of magmatism and contemporaneous detrital zircon $\mathrm{U}-\mathrm{Pb}$ ages have been confirmed in the southwestern [11,14,67-69] and southeastern margins of the Yangtze Block (Figure $5 b, d$ ). Thus, the major contributor to these $\sim 1.60 \mathrm{Ga}$ detrital zircons may lie in the Yangtze Block itself rather than an external continent. At ca. 1.60 Ga the Qinling Belt was part of the South China Craton, and the proto-Yangtze Block may have been located in the position at the nexus of north Laurentia, southwest Siberia, and north Austria [70]. Thus, they could also have served as sources for $\sim 1.60 \mathrm{Ga}$ detrital zircons. Li et al. [19] proposed that the Dagushi Gp correlates well with the Shennongjia Gp in terms of sedimentology and geochronology. The newly acquired $\sim 1.60 \mathrm{Ga}$ detrital zircon ages and corresponding $\varepsilon \mathrm{Hf}_{(\mathrm{t})}$ values reported in this study (Figure 6a) further corroborate this correlation. Both groups are interpreted to have formed in a continental rift setting [17], as suggested by the occurrence of intra-plate alkali and tholeiitic basalts in the Shennongjia Gp [71]. Wang et al. [72] suggested that the Shennongjia Gp was deposited during a transgressive system tract in a carbonate ramp steepening toward the west. The clastic rocks are widely distributed in the Shennongjia strata, suggesting continued terrestrial material input mainly from the ancient Yangtze land to the south. These lines of evidence suggest that the $\sim 1.60$ Ga detrital zircons of the Dagushi Gp may have also been derived 
from the interior of the Yangtze Block. In addition, the narrow age spectrum and $\varepsilon \mathrm{Hf}_{(\mathrm{t})}$ values of these zircons favor a single source.
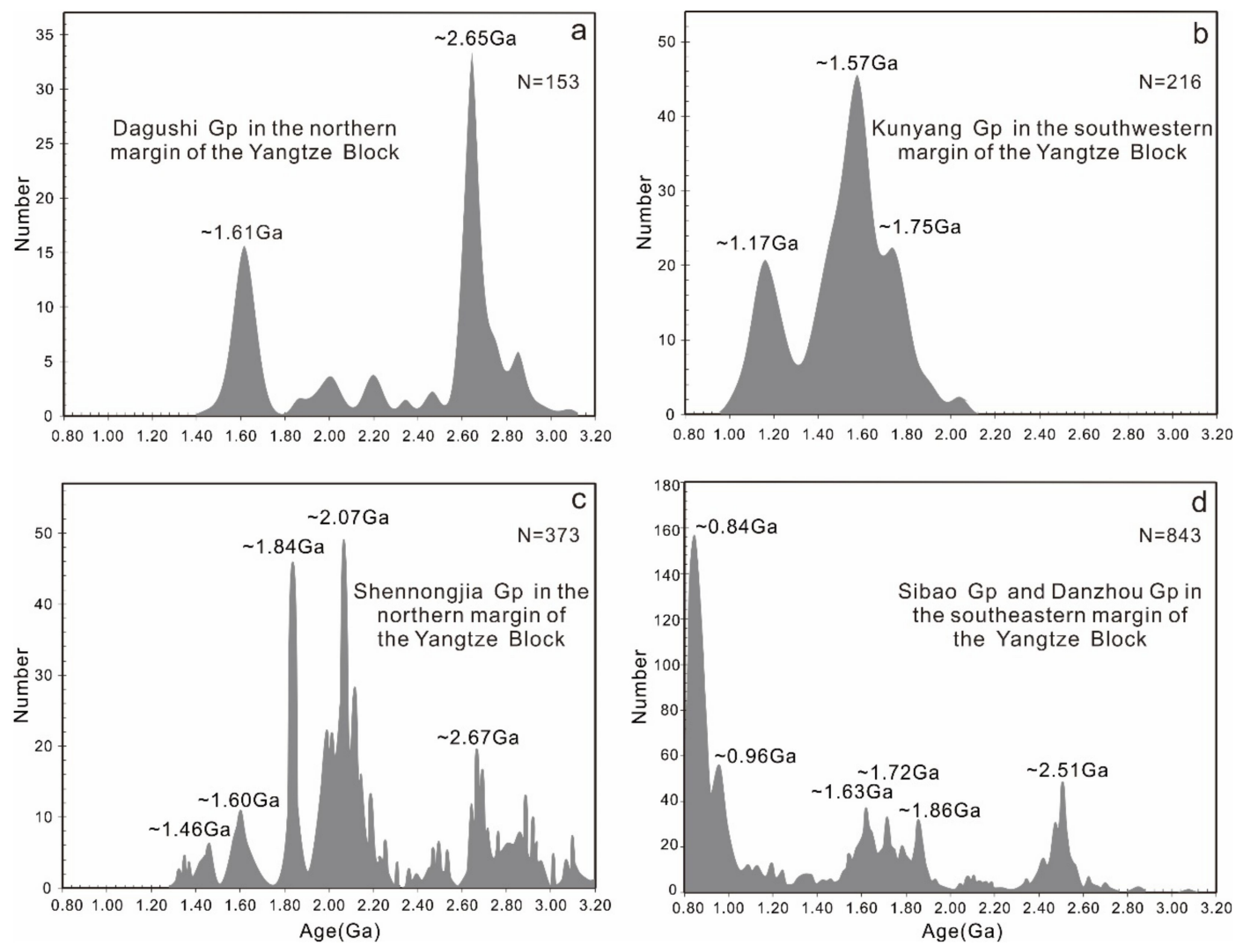

Figure 5. Age probability diagrams of detrital zircons from Precambrian metasedimentary rocks in the South China Block [18,21,68,73-80]. (a) age probability diagrams of detrital zircons from the Dagushi Gp; (b) age probability diagrams of detrital zircons from the Kunyang Gp; (c) age probability diagrams of detrital zircons from the Shennongjia Gp; (d) age probability diagrams of detrital zircons from the Sibao Gp and Danzhou Gp.
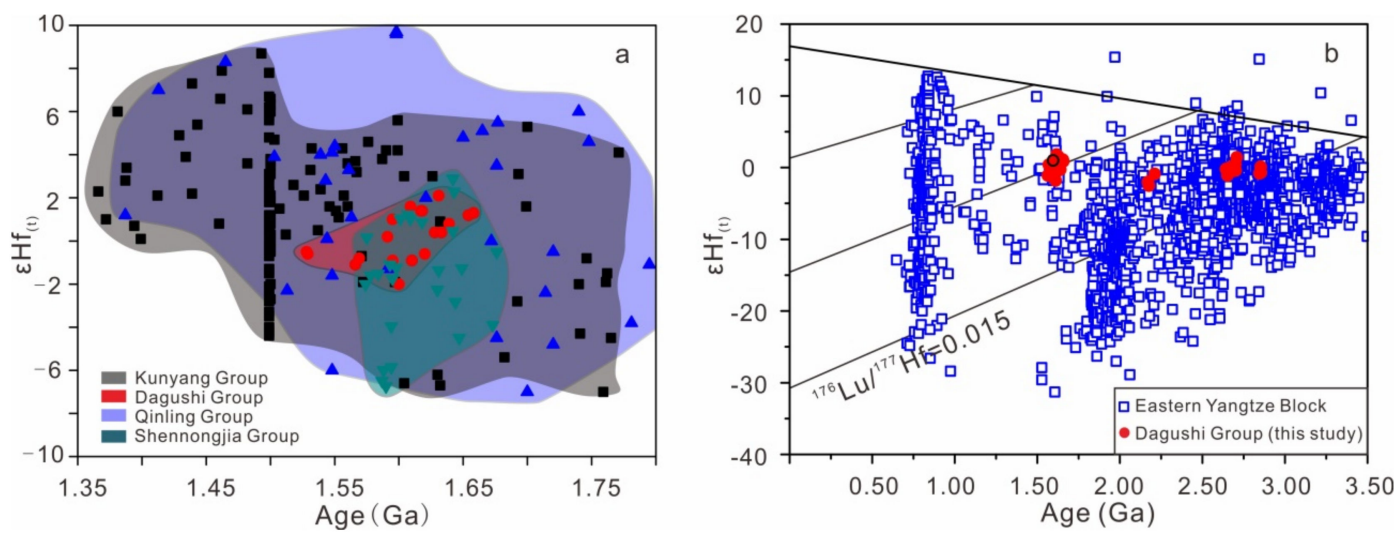

Figure 6. (a) A comparison of $\epsilon \mathrm{Hf}_{(\mathrm{t})}$ values of 1800-1350 Ma zircons from the Mesoproterozoic strata in the northern and western margins of the Yangtze Block [18,70,81]; (b) plots of $\varepsilon \mathrm{Hf}_{(\mathrm{t})}$ values versus crystallization ages for detrital zircons from the eastern Yangtze Block (data are from Yang et al. [26] and references therein, as well as this study).

\subsection{Tectonic Setting for Sedimentation of the Dagushi Gp}

Indications of magmatic events between $\sim 1.75 \mathrm{Ga}$ and $\sim 1.50 \mathrm{Ga}$ are commonly recorded at the southwestern margin of the Yangtze Block. The rock assemblages are dominated by alkaline-subalkaline metamorphosed mafic volcanic rock and gabbro-diabase 
dikes constituting a bimodal distribution together with minor A-type granites [82]. Most rocks have high Ti and rare earth and trace element patterns similar to those of continental flood basalts (CFB) and ocean island basalts (OIB) [8,10-12], while some show enriched midocean ridge basalt (E-MORB) or transitional features between E-MORB and OIB [83-85]. All fall into within-plate basalt fields on the $\mathrm{Zr} / \mathrm{Y}-\mathrm{Zr}$, Ti/100-Zr-Y $\times 3, \mathrm{Hf} / 3-\mathrm{Th}-\mathrm{Ta}$, and $\mathrm{Nb} \times 2-\mathrm{Zr} / 4-\mathrm{Y}$ diagrams [83-85].

The $\epsilon \mathrm{Hf}_{(\mathrm{t})}$ values of $\sim 1.80-1.35 \mathrm{Ga}$ zircons in the northern and western margin of the Yangtze Block overlap (Figure 6a), indicating the similarity of their sources. The $\epsilon \mathrm{Hf}_{(\mathrm{t})}$ values are significantly elevated at $\sim 1.60-1.40 \mathrm{Ga}$, as illustrated by the evolution curve of ancient rocks in the interior of the Yangtze Block (Figure 6b). Additionally, Xiao [18] reported zircon $\delta^{18} \mathrm{O}$ values between +5.41 and +5.67 , suggesting that mantle-derived materials were added to the crust during this period. Trace element compositions of zircon are useful for delineating its source rock types [86], and those of $~ 1.60$ Ga detrital zircons from the Dagushi Gp are shown in Figure 7 and in Table A6 (Appendix A). According to the classification and regression tree (CART-tree) model (Figure 7a, [86]), the source rocks of detrital zircons from the Dagushi Gp are mainly basic (Figure 7b).
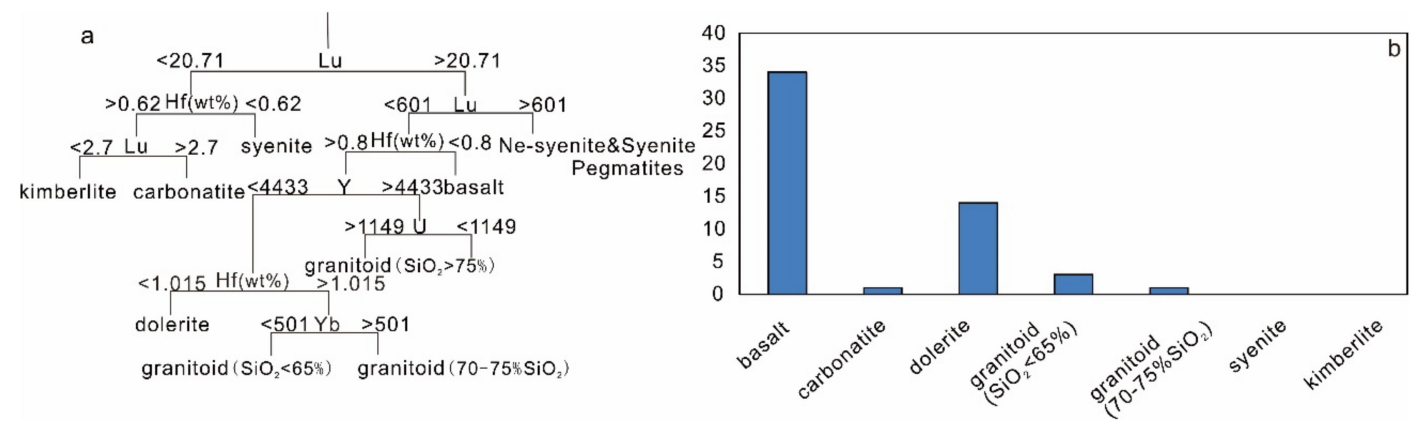

Figure 7. (a) Classification and regression tree (CART-tree) for classification of zircons by rock types [86]; (b) source rock types of $\sim 1.60 \mathrm{Ga}$ zircons from the Dagushi Gp.

Broadly speaking, trace element characteristics of magmatic zircon could also reflect the compositions of its source magma and the crystalline environment [86,87]. The ca. $1.60 \mathrm{Ga}$ detrital zircons from the Dagushi Gp have a median $\mathrm{Nb}$ concentration of $17 \mathrm{ppm}$, significantly higher than that of continental arcs (1.7 ppm) and MOR (1.6 ppm) [88]. In addition, they have $\mathrm{U} / \mathrm{Yb}$ ratios (mostly $0.1-1.3$ ) intermediate between those of MOR and typical continental crustal zircons, but higher than Icelandic basalt [89]. On the Hf/Th$\mathrm{Th} / \mathrm{Nb}$ and $\mathrm{Nb} / \mathrm{Hf} \times 10,000-\mathrm{Th} / \mathrm{U}$ discrimination diagrams (Figure $8 \mathrm{a}, \mathrm{b}$ ), zircons from the Dagushi Gp mostly fall in the field of within-plate/anorogenic environments. On the $\mathrm{U} / \mathrm{Yb}-\mathrm{Hf}$ and $\mathrm{U} / \mathrm{Yb}-\mathrm{Nb} / \mathrm{Yb} \times 10,000$ discrimination diagrams (Figure $8 \mathrm{c}, \mathrm{d}$ ), they mostly plot in the Hawaii-Iceland field. A subset of zircons with high U/Yb and Hf/Th ratios fall outside the within-plate area (Figure 8a,d), which can be attributed to the fractional crystallization of minerals such as titanite, ilmenite, and zircon. These minerals exert a dominant control on the $\mathrm{U}, \mathrm{Yb}, \mathrm{Nb}$, and $\mathrm{Hf}$ elements of the remaining melt, and they enrich $\mathrm{U}$ and $\mathrm{Hf}$ in later-formed grains [88]. We interpret the source rocks to have been formed in an intra-plate rifting environment, according to the $\mathrm{Hf}$ and $\mathrm{O}$ isotope and zircon trace element compositions.

Xiong and Chen [17] argued that the Shennongjia Gp and Dagushi Gp were deposited in the Mesoproterozoic aulacogen at the northern margin of the Yangtze Block. Li et al. [21] believed that the upper subgroup of the Shennongjia Gp and the Dagushi Gp represented a shallow marine environment at the margin of the initial rift basin. Liu et al. [71] reported a set of metabasalt (alkaline basalt series)-tuff (tholeiite basalt series) assemblages from the Shicaohe Fm of the Shennongjia Gp, and they attributed their geochemical characteristics to within-plate rift basalts. These lines of evidence may indicate a long-term rifting history in the northern margin of the Yangtze Block during the Mesoproterozoic. 

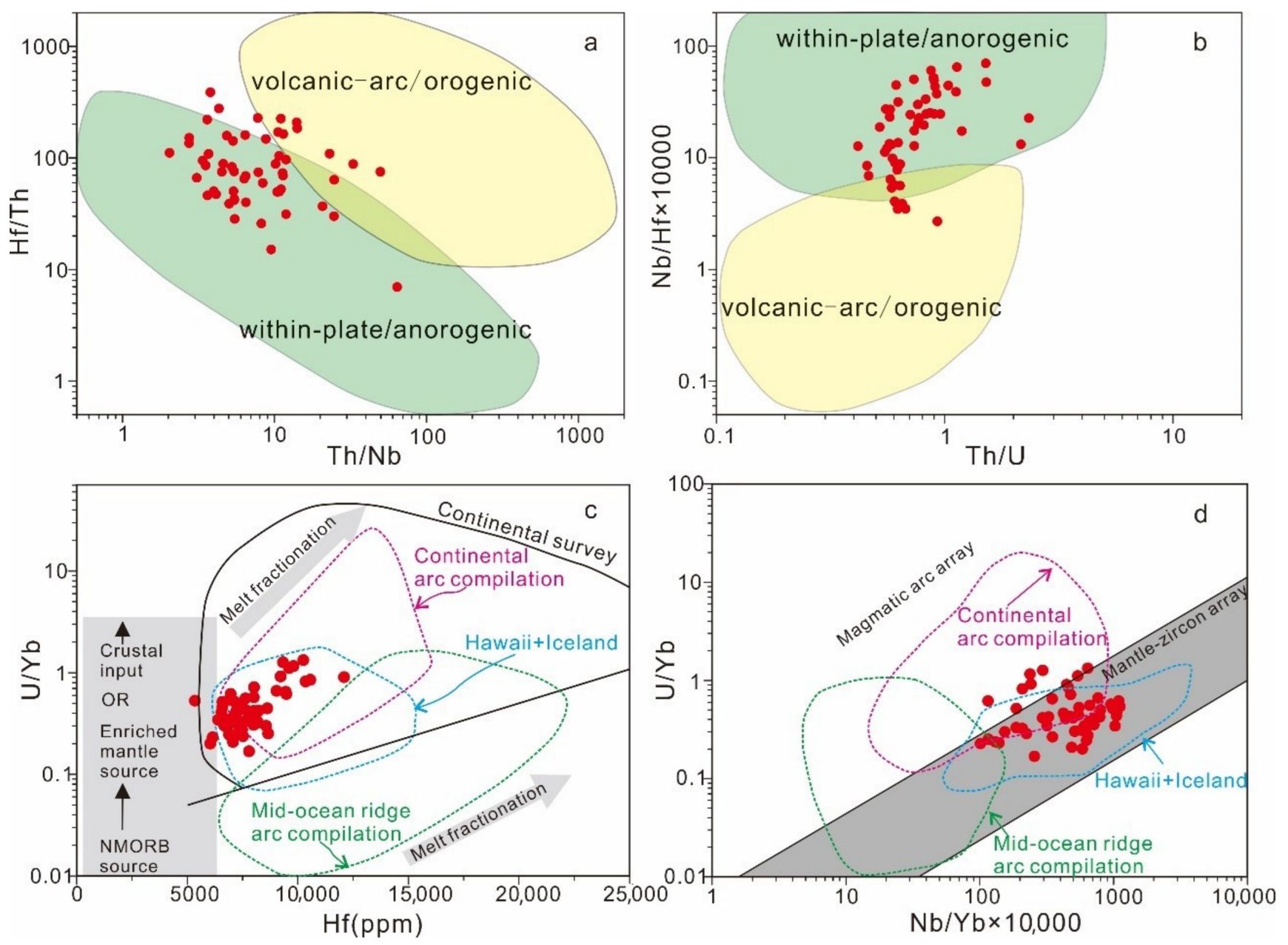

Figure 8. (a) Plot of Hf/Th vs. Th/Nb; (b) plot of $\mathrm{Nb} / \mathrm{Hf} \times 10,000$ vs. Th/U; (c) plot of U/Yb vs. Hf; (d) plot of U/Yb vs. $\mathrm{Nb} / \mathrm{Yb} \times 10,000[88,90-92]$.

\subsection{Reconstruction of the Supercontinent Columbia}

Active continental margin magmatism occurred along the margin of the supercontinent Columbia at ca. 1.80-1.40 Ga, with rift-type magmatic pulses in its interior [93]. Detrital zircons dated at ca. 1.70-1.50 Ga are documented from the western, southwestern, and northern margins of the Yangtze Block, as well as in minor amounts from the southeastern margin of the Yangtze Block; in contrast, these Paleo- to Mesoproterozoic detrital zircons are rare in the interior of the Yangtze Block [20]. As discussed above, ca. 1.60 Ga detrital zircons of the Dagushi Gp and Shennongia Gp have nearly chondritic Hf isotope composition, mantle-source oxygen isotope composition, and primitive properties of basalts, which are trace element characteristics of intra-plate magma, indicating a derivation from typical intra-plate magmatic events. Thus, we suggest that extensive break-up may have occurred at the periphery of the Yangtze Block, responding to the fragmentation of the supercontinent Columbia. Meanwhile, widespread $\sim 1.60-1.30 \mathrm{Ga}$ Mesoproterozoic post-orogenic and anorogenic magmatism has been identified in many Precambrian cratons, including the $\sim 1.60 \mathrm{Ga}$ Dalma magmatic rocks in northeast India [94], the 1.59 Ga tholeiitic dyke swarms in South America [95], the 1.50 Ga mafic dykes in South America [96], and the ca. $1.50 \mathrm{Ga}$ mafic magmatism in South China [8]. The marked contrast with arc magmatism at the margin of the supercontinent Columbia [97-99] further suggests that the Yangtze Block may have been located at the center of the supercontinent Columbia (Figure 9). 


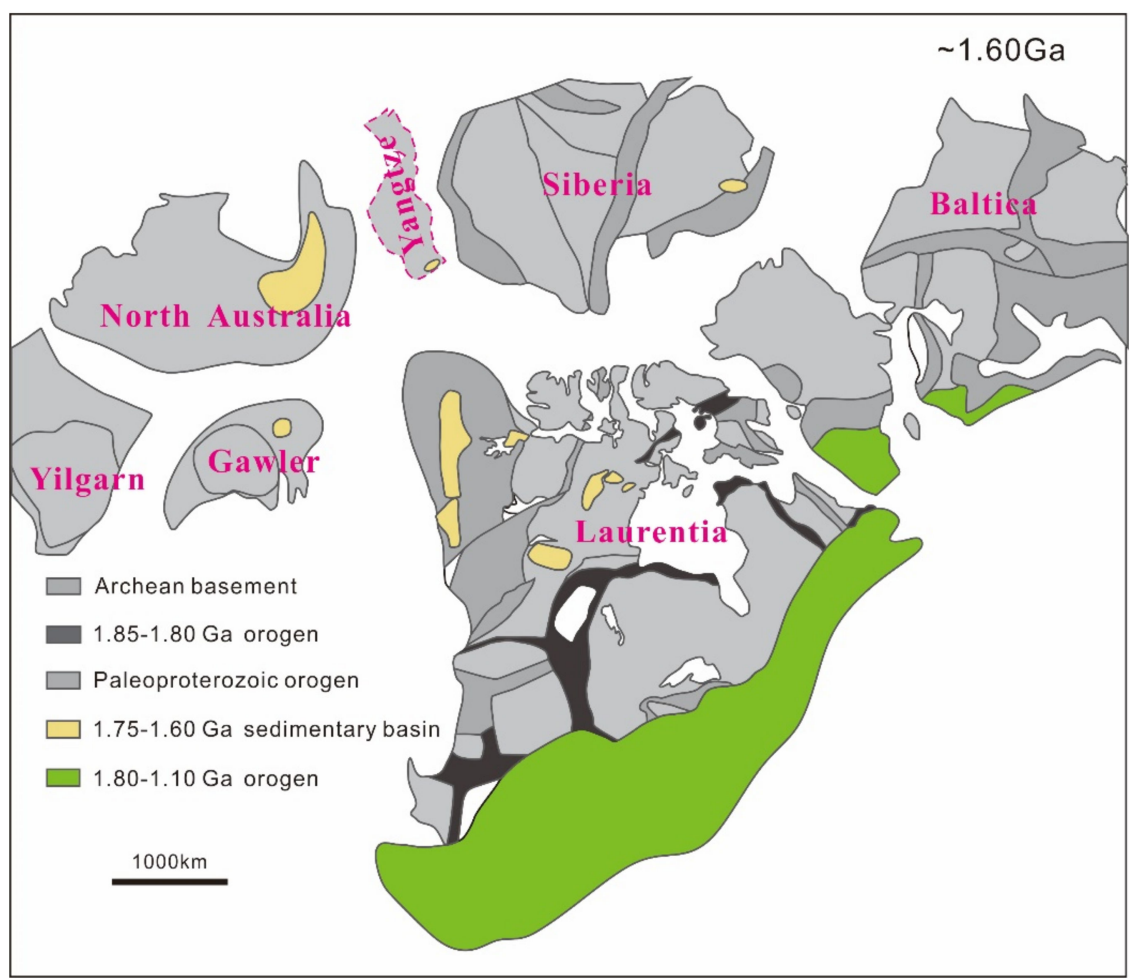

Figure 9. The position of the Yangtze Block in the reconstruction of the supercontinent Columbia (modified after $[7,100])$.

\section{Conclusions}

(1) The detrital zircon spectra of the Dagushi Gp shows two distinct age peaks of $\sim 2.65 \mathrm{Ga}$ and $\sim 1.60 \mathrm{Ga}$, which are compatible with the magmatism reported from the Yangtze Block. Sedimentological and geochronological comparisons between the Dagushi and the Shennongjia groups indicate that the groups were probably coeval units. Provenance studies suggest the sediments of the Dagushi Gp could be derived from mafic source regions within the Yangtze Block.

(2) The $\sim 1.60 \mathrm{Ga}$ ages first discovered yield a narrow range of $\epsilon \mathrm{Hf}_{(\mathrm{t})}$ values from -1.8 to +1.8 , which lie above the old crust evolutionary line of the Yangtze Block, suggesting the addition of mantle material.

(3) Most $~ 1.60 \mathrm{Ga}$ detrital zircons are plotted into the within-plate/anorogenic field. The Yangtze Block was likely a fragment of the Paleo- to Mesoproterozoic supercontinent Columbia and may have been located in its center rather than its margin.

Author Contributions: Conceptualization, X.X. and Z.Y.; methodology, X.X.; software, H.Z.; validation, X.X. and Z.Y.; investigation, Y.X. and X.D.; data curation, H.Z.; writing-original draft preparation, X.X. and H.Z.; writing-review and editing, Z.Y. and A.P.; supervision, Z.Y.; funding acquisition, Z.Y. All authors have read and agreed to the published version of the manuscript.

Funding: This study was supported by the Natural Science Foundation of Hebei Province (Grant No. D2020403095), the National Natural Science Foundation of China (Grant Nos. 41172189 and 41472190), and the China Geological Survey Bureau (Grant No. DD20190050).

Data Availability Statement: The data presented in this study are available on request from the corresponding author. The data are not publicly available due to the research process of this project.

Conflicts of Interest: The authors declare no conflict of interest. 


\section{Appendix A}

Table A1. LA-ICP-MS U-Pb isotopic data of standard zircons.

\begin{tabular}{|c|c|c|c|c|c|c|c|c|c|c|c|c|c|c|c|c|c|}
\hline \multirow{2}{*}{$\begin{array}{c}\text { Analysis } \\
\text { No. }\end{array}$} & \multirow{2}{*}{$\begin{array}{c}\text { Sample } \\
\text { Name }\end{array}$} & \multirow{2}{*}{$\begin{array}{c}\mathrm{Pb} \\
(\mathrm{ppm})\end{array}$} & \multirow{2}{*}{$\begin{array}{c}\text { Th } \\
\text { (ppm) }\end{array}$} & \multirow{2}{*}{$\begin{array}{c}\mathrm{U} \\
(\mathrm{ppm})\end{array}$} & \multicolumn{6}{|c|}{ Isotopic Ratios } & \multicolumn{6}{|c|}{ Age (Ma) } & \multirow{2}{*}{ Concordia } \\
\hline & & & & & ${ }^{207} \mathrm{~Pb} /{ }^{206} \mathrm{~Pb}$ & $1 \sigma$ & ${ }^{207} \mathrm{~Pb} /{ }^{235} \mathrm{~Pb}$ & $1 \sigma$ & ${ }^{206} \mathrm{~Pb} /{ }^{238} \mathrm{~Pb}$ & $1 \sigma$ & ${ }^{207} \mathrm{~Pb} /{ }^{206} \mathrm{~Pb}$ & $1 \sigma$ & ${ }^{207} \mathrm{~Pb} /{ }^{235} \mathrm{~Pb}$ & $1 \sigma$ & ${ }^{206} \mathrm{~Pb} /{ }^{238} \mathrm{~Pb}$ & $1 \sigma$ & \\
\hline \multicolumn{18}{|c|}{ Standard Zircon 91500 as an External Standard (Reference ${ }^{206} \mathrm{~Pb} /{ }^{238} \mathrm{U}$ Age $=1062.4 \pm 0.8 \mathrm{Ma}, 2 \sigma[31]$ ) } \\
\hline \multicolumn{18}{|l|}{ JS14-1 } \\
\hline SEP16A02 & 91500std & 83 & 80 & 230 & 0.0748 & 0.0022 & 1.8589 & 0.0540 & 0.1805 & 0.0026 & 1065 & 56 & 1067 & 19 & 1070 & 14 & $99 \%$ \\
\hline SEP16A03 & 91500 std & 83 & 82 & 233 & 0.0749 & 0.0022 & 1.8415 & 0.0543 & 0.1778 & 0.0026 & 1133 & 59 & 1060 & 19 & 1055 & 14 & $99 \%$ \\
\hline SEP16A07 & 91500 std & 83 & 83 & 235 & 0.0749 & 0.0019 & 1.8502 & 0.0464 & 0.1792 & 0.0024 & 1065 & 51 & 1064 & 17 & 1062 & 13 & $99 \%$ \\
\hline SEP16A15 & 91500 std & 85 & 82 & 235 & 0.0744 & 0.0022 & 1.8281 & 0.0524 & 0.1785 & 0.0026 & 1051 & 59 & 1056 & 19 & 1059 & 14 & $99 \%$ \\
\hline SEP16A16 & 91500std & 83 & 81 & 231 & 0.0754 & 0.0023 & 1.8723 & 0.0558 & 0.1798 & 0.0026 & 1080 & 61 & 1071 & 20 & 1066 & 14 & $99 \%$ \\
\hline SEP16A23 & 91500 std & 84 & 81 & 235 & 0.0749 & 0.0021 & 1.8502 & 0.0517 & 0.1792 & 0.0024 & 1065 & 56 & 1064 & 18 & 1062 & 13 & $99 \%$ \\
\hline SEP16A31 & 91500 std & 83 & 80 & 230 & 0.0752 & 0.0025 & 1.8576 & 0.0639 & 0.1788 & 0.0026 & 1074 & 67 & 1066 & 23 & 1060 & 14 & $99 \%$ \\
\hline SEP16A32 & 91500 std & 82 & 81 & 233 & 0.0746 & 0.0025 & 1.8428 & 0.0601 & 0.1796 & 0.0026 & 1057 & 67 & 1061 & 21 & 1065 & 14 & $99 \%$ \\
\hline SEP16A39 & 91500std & 83 & 81 & 231 & 0.0773 & 0.0025 & 1.9048 & 0.0644 & 0.1784 & 0.0026 & 1129 & 66 & 1083 & 23 & 1058 & 14 & $97 \%$ \\
\hline SEP16A40 & 91500 std & 93 & 91 & 258 & 0.0725 & 0.0023 & 1.7956 & 0.0571 & 0.1799 & 0.0026 & 998 & 64 & 1044 & 21 & 1066 & 14 & $97 \%$ \\
\hline SEP16A48 & 91500 std & 86 & 82 & 234 & 0.0738 & 0.0023 & 1.8224 & 0.0595 & 0.1791 & 0.0027 & 1035 & 63 & 1054 & 21 & 1062 & 15 & $99 \%$ \\
\hline SEP16A49 & 91500std & 84 & 82 & 236 & 0.0760 & 0.0024 & 1.8780 & 0.0611 & 0.1792 & 0.0026 & 1094 & 68 & 1073 & 22 & 1063 & 14 & $99 \%$ \\
\hline SEP16A56 & 91500 std & 84 & 82 & 233 & 0.0755 & 0.0024 & 1.8716 & 0.0583 & 0.1797 & 0.0028 & 1083 & 62 & 1071 & 21 & 1066 & 15 & $99 \%$ \\
\hline SEP16A57 & 91500 std & 84 & 79 & 231 & 0.0742 & 0.0024 & 1.8288 & 0.0604 & 0.1786 & 0.0028 & 1048 & 71 & 1056 & 22 & 1059 & 15 & $99 \%$ \\
\hline SEP16A64 & 91500 std & 83 & 81 & 233 & 0.0749 & 0.0021 & 1.8502 & 0.0504 & 0.1792 & 0.0024 & 1065 & 56 & 1064 & 18 & 1062 & 13 & $99 \%$ \\
\hline SEP16A72 & 91500 std & 90 & 85 & 244 & 0.0767 & 0.0024 & 1.8961 & 0.0586 & 0.1791 & 0.0027 & 1122 & 62 & 1080 & 21 & 1062 & 15 & $98 \%$ \\
\hline SEP16A73 & 91500 std & 85 & 82 & 238 & 0.0731 & 0.0023 & 1.8043 & 0.0568 & 0.1793 & 0.0027 & 1017 & 65 & 1047 & 21 & 1063 & 15 & $98 \%$ \\
\hline SEP16A91 & 91500 std & 81 & 81 & 232 & 0.0741 & 0.0023 & 1.8402 & 0.0583 & 0.1797 & 0.0028 & 1056 & 63 & 1060 & 21 & 1066 & 16 & $99 \%$ \\
\hline SEP16A92 & 91500 std & 86 & 81 & 236 & 0.0756 & 0.0024 & 1.8602 & 0.0583 & 0.1786 & 0.0028 & 1087 & 65 & 1067 & 21 & 1059 & 15 & $99 \%$ \\
\hline $\begin{array}{c}\text { Average } \\
N=21\end{array}$ & & 85 & 82 & 235 & 0.0749 & 0.0023 & 1.8502 & 0.0573 & 0.1792 & 0.0026 & 1070 & 62 & 1063 & 20 & 1062 & 14 & \\
\hline \multicolumn{18}{|l|}{ JS14-2 } \\
\hline JUN22F02 & 91500std & 31 & 31 & 84 & 0.074351 & 0.002171 & 1.819084 & 0.052852 & 0.177726 & 0.002108 & 1051 & 59 & 1052 & 19 & 1055 & 12 & $99 \%$ \\
\hline JUN22F03 & 91500 std & 30 & 30 & 81 & 0.075409 & 0.002125 & 1.881316 & 0.055478 & 0.180614 & 0.002297 & 1080 & 61 & 1075 & 20 & 1070 & 13 & $99 \%$ \\
\hline JUN22F14 & 91500 std & 30 & 29 & 81 & 0.075724 & 0.002173 & 1.859439 & 0.050115 & 0.178574 & 0.002645 & 1087 & 57 & 1067 & 18 & 1059 & 14 & $99 \%$ \\
\hline JUN22F15 & 91500 std & 31 & 30 & 82 & 0.074036 & 0.002178 & 1.840961 & 0.052061 & 0.179766 & 0.002259 & 1043 & 59 & 1060 & 19 & 1066 & 12 & $99 \%$ \\
\hline JUN22F22 & 91500std & 29 & 30 & 82 & 0.073122 & 0.002133 & 1.796333 & 0.054674 & 0.177865 & 0.002199 & 1017 & 55 & 1044 & 20 & 1055 & 12 & $98 \%$ \\
\hline JUN22F23 & 91500 std & 31 & 29 & 81 & 0.076638 & 0.002296 & 1.904067 & 0.059651 & 0.180475 & 0.002345 & 1122 & 61 & 1083 & 21 & 1070 & 13 & $98 \%$ \\
\hline JUN22F30 & 91500 std & 31 & 30 & 83 & 0.076342 & 0.002141 & 1.900045 & 0.051711 & 0.181332 & 0.002255 & 1106 & 52 & 1081 & 18 & 1074 & 12 & $99 \%$ \\
\hline JUN22F31 & 91500 std & 31 & 31 & 85 & 0.073418 & 0.001879 & 1.800355 & 0.048089 & 0.177008 & 0.001911 & 1026 & 52 & 1046 & 17 & 1051 & 10 & $99 \%$ \\
\hline JUN22F38 & 91500 std & 31 & 30 & 83 & 0.074426 & 0.002088 & 1.845738 & 0.052396 & 0.179976 & 0.002436 & 1054 & 57 & 1062 & 19 & 1067 & 13 & $99 \%$ \\
\hline JUN22F39 & 91500 std & 31 & 31 & 83 & 0.075334 & 0.002264 & 1.854662 & 0.056284 & 0.178364 & 0.002215 & 1077 & 60 & 1065 & 20 & 1058 & 12 & $99 \%$ \\
\hline JUN22F46 & 91500 std & 30 & 30 & 82 & 0.073506 & 0.002322 & 1.823339 & 0.058917 & 0.179551 & 0.002457 & 1028 & 69 & 1054 & 21 & 1065 & 13 & $98 \%$ \\
\hline
\end{tabular}


Table A1. Cont.

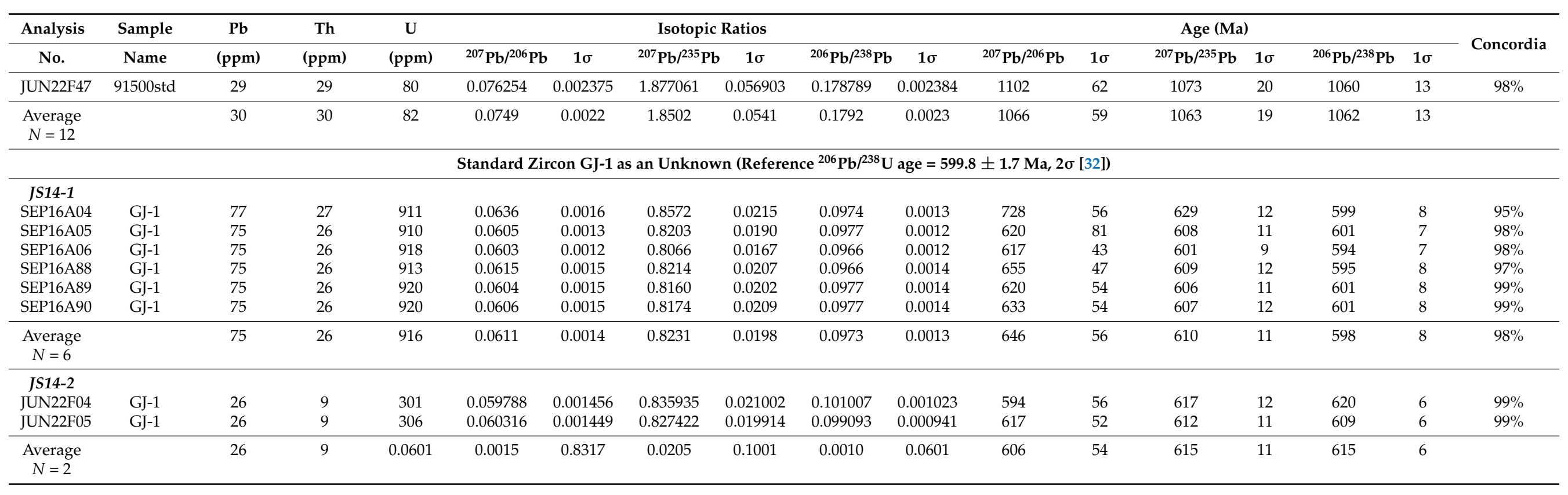

Table A2. Trace element data of standard zircons.

\begin{tabular}{|c|c|c|c|c|c|c|c|c|c|c|c|c|c|c|c|c|c|c|c|}
\hline Spot No. & $\mathrm{Ti}$ & $Y$ & $\mathrm{Nb}$ & $\mathrm{Ce}$ & $\mathrm{Nd}$ & $\mathrm{Sm}$ & $\mathbf{E u}$ & $\mathrm{Gd}$ & $\mathrm{Tb}$ & Dy & Нo & Er & $\mathrm{Tm}$ & $\mathrm{Yb}$ & $\mathbf{L u}$ & $\mathrm{Hf}$ & Ta & Th & $\mathbf{U}$ \\
\hline \multicolumn{20}{|l|}{ JS14-1 } \\
\hline NIST-610 & 437 & 439 & 420 & 444 & 435 & 454 & 461 & 443 & 443 & 426 & 447 & 421 & 423 & 465 & 428 & 375 & 452 & 451.9 & 425.7 \\
\hline NIST-610 & 437 & 439 & 420 & 444 & 435 & 454 & 461 & 443 & 443 & 426 & 447 & 421 & 423 & 465 & 428 & 375 & 452 & 451.9 & 425.7 \\
\hline NIST-610 & 437 & 439 & 420 & 444 & 435 & 454 & 461 & 443 & 443 & 426 & 447 & 421 & 423 & 465 & 428 & 375 & 452 & 451.9 & 425.7 \\
\hline 91500std & 4.6 & 135 & 0.77 & 2.58 & 0.06 & 0.4 & 0.16 & 2.01 & 0.83 & 11.0 & 4.64 & 24.1 & 6.05 & 67.0 & 13.0 & 5780 & 0.5 & 28.9 & 77 \\
\hline 91500std & 3.5 & 141 & 0.75 & 2.62 & 0.27 & 0.4 & 0.24 & 2.24 & 0.92 & 11.6 & 4.91 & 24.8 & 6.44 & 69.6 & 13.4 & 5852 & 0.6 & 30.2 & 80 \\
\hline 91500std & 5.1 & 139 & 0.80 & 2.79 & 0.01 & 0.0 & 0.21 & 2.05 & 0.88 & 11.3 & 4.79 & 24.7 & 6.35 & 69.3 & 13.5 & 5750 & 0.5 & 30.0 & 79 \\
\hline 91500std & 3.0 & 136 & 0.77 & 2.75 & 0.23 & 0.3 & 0.25 & 1.97 & 0.83 & 11.4 & 4.66 & 23.2 & 6.11 & 67.3 & 13.3 & 5668 & 0.5 & 29.0 & 83 \\
\hline 91500std & 5.3 & 139 & 0.70 & 2.58 & 0.15 & 0.5 & 0.33 & 2.46 & 0.82 & 11.2 & 4.70 & 24.8 & 6.29 & 69.2 & 13.3 & 5756 & 0.6 & 29.3 & 78 \\
\hline 91500std & 4.4 & 137 & 0.70 & 2.73 & 0.16 & 0.4 & 0.26 & 2.28 & 0.93 & 10.6 & 4.60 & 24.4 & 6.15 & 68.2 & 13.1 & 5702 & 0.6 & 28.8 & 77 \\
\hline
\end{tabular}


Table A2. Cont.

\begin{tabular}{|c|c|c|c|c|c|c|c|c|c|c|c|c|c|c|c|c|c|c|c|}
\hline Spot No. & $\mathrm{Ti}$ & $Y$ & $\mathrm{Nb}$ & $\mathrm{Ce}$ & $\mathrm{Nd}$ & $\mathrm{Sm}$ & $\mathbf{E u}$ & $\mathrm{Gd}$ & $\mathrm{Tb}$ & Dy & Нo & Er & $\mathrm{Tm}$ & $\mathrm{Yb}$ & $\mathbf{L u}$ & $\mathrm{Hf}$ & $\mathrm{Ta}$ & Th & $\mathbf{U}$ \\
\hline 91500std & 2.9 & 135 & 0.66 & 2.69 & 0.26 & 0.6 & 0.23 & 1.98 & 0.84 & 11.5 & 4.78 & 23.7 & 6.26 & 67.3 & 13.2 & 5749 & 0.5 & 29.3 & 78 \\
\hline 91500std & 3.5 & 136 & 0.64 & 2.84 & 0.24 & 0.3 & 0.26 & 2.21 & 0.91 & 11.3 & 4.55 & 24.2 & 6.29 & 67.7 & 13.2 & 5729 & 0.5 & 28.6 & 77 \\
\hline 91500std & 6.2 & 139 & 0.70 & 2.66 & 0.14 & 0.3 & 0.22 & 2.13 & 0.90 & 11.1 & 4.78 & 24.6 & 6.14 & 68.7 & 13.3 & 5715 & 0.5 & 29.3 & 79 \\
\hline 91500std & 4.9 & 138 & 0.70 & 2.43 & 0.23 & 0.5 & 0.21 & 2.33 & 0.89 & 11.9 & 4.93 & 25.5 & 6.34 & 69.1 & 13.5 & 5850 & 0.6 & 29.6 & 79 \\
\hline 91500std & 3.5 & 151 & 0.67 & 2.69 & 0.15 & 0.5 & 0.34 & 2.15 & 0.90 & 12.3 & 5.38 & 27.7 & 6.74 & 75.0 & 14.7 & 5888 & 0.6 & 33.5 & 89 \\
\hline 91500std & 4.1 & 142 & 0.70 & 2.73 & 0.33 & 0.5 & 0.23 & 2.14 & 0.98 & 11.4 & 4.75 & 25.6 & 6.50 & 70.5 & 13.7 & 5916 & 0.6 & 30.4 & 81 \\
\hline 91500 std & 7.2 & 142 & 0.79 & 2.82 & 0.04 & 0.6 & 0.35 & 2.29 & 0.80 & 11.3 & 4.86 & 25.0 & 6.49 & 70.2 & 13.8 & 5879 & 0.5 & 30.6 & 82 \\
\hline 91500std & 4.8 & 144 & 0.70 & 2.94 & 0.13 & 0.5 & 0.26 & 2.44 & 0.91 & 11.8 & 5.01 & 25.7 & 6.66 & 71.5 & 13.8 & 5948 & 0.6 & 30.9 & 82 \\
\hline 91500std & 6.9 & 139 & 0.72 & 2.71 & 0.20 & 0.3 & 0.22 & 2.15 & 0.82 & 11.5 & 4.74 & 25.2 & 6.10 & 69.6 & 13.5 & 5831 & 0.6 & 29.8 & 80 \\
\hline 91500std & 5.7 & 140 & 0.72 & 2.64 & 0.38 & 0.6 & 0.22 & 1.82 & 0.90 & 11.5 & 4.77 & 24.7 & 6.22 & 70.4 & 13.7 & 5900 & 0.6 & 30.2 & 81 \\
\hline 91500std & 6.5 & 149 & 0.75 & 2.74 & 0.19 & 0.5 & 0.36 & 2.32 & 0.97 & 12.2 & 5.33 & 26.6 & 6.89 & 75.4 & 14.6 & 6309 & 0.6 & 31.8 & 85 \\
\hline 91500std & 5.8 & 150 & 0.65 & 2.98 & 0.11 & 0.5 & 0.27 & 2.94 & 0.93 & 12.3 & 5.17 & 26.3 & 6.68 & 73.6 & 14.4 & 6079 & 0.6 & 32.6 & 87 \\
\hline 91500std & 6.7 & 150 & 0.79 & 2.82 & 0.31 & 0.4 & 0.26 & 2.75 & 0.98 & 12.1 & 5.36 & 26.9 & 6.70 & 75.3 & 14.6 & 6248 & 0.6 & 31.9 & 86 \\
\hline 91500std & 5.4 & 144 & 0.71 & 2.88 & 0.18 & 0.6 & 0.31 & 2.52 & 0.90 & 12.0 & 5.02 & 26.1 & 6.72 & 72.9 & 14.4 & 6136 & 0.6 & 30.7 & 83 \\
\hline 91500std & 4.5 & 151 & 0.62 & 2.99 & 0.00 & 0.3 & 0.37 & 2.58 & 0.82 & 12.7 & 5.27 & 27.5 & 7.07 & 75.0 & 14.8 & 6154 & 0.6 & 33.2 & 87 \\
\hline 91500std & 2.2 & 146 & 0.71 & 2.75 & 0.27 & 0.6 & 0.27 & 2.40 & 0.93 & 12.1 & 4.99 & 26.2 & 6.72 & 72.9 & 14.4 & 6213 & 0.6 & 31.3 & 83 \\
\hline 91500std & 5.9 & 149 & 0.77 & 2.79 & 0.21 & 0.3 & 0.20 & 2.51 & 0.93 & 12.0 & 5.34 & 27.7 & 6.86 & 76.0 & 14.8 & 6325 & 0.6 & 32.2 & 86 \\
\hline GJ-1 & 2.78 & 249 & 1.56 & 16.9 & 0.73 & 1.38 & 0.95 & 7.1 & 2.07 & 20.6 & 7.20 & 29.6 & 6.56 & 66.8 & 12.8 & 6779 & 0.46 & 10.01 & 317 \\
\hline GJ-1 & 2.04 & 248 & 1.73 & 16.5 & 0.67 & 1.53 & 0.98 & 6.9 & 1.95 & 20.4 & 6.97 & 29.9 & 6.32 & 65.8 & 13.1 & 6702 & 0.49 & 9.68 & 312 \\
\hline GJ-1 & 3.37 & 251 & 1.62 & 16.8 & 0.58 & 1.77 & 0.95 & 7.1 & 2.07 & 20.3 & 7.04 & 30.5 & 6.56 & 66.4 & 13.2 & 6800 & 0.45 & 9.82 & 320 \\
\hline GJ-1 & 4.70 & 270 & 1.75 & 18.3 & 0.75 & 1.63 & 0.91 & 7.7 & 2.17 & 23.4 & 7.94 & 33.5 & 7.18 & 71.5 & 14.3 & 7466 & 0.49 & 10.63 & 348 \\
\hline \multicolumn{20}{|l|}{ JS14-2 } \\
\hline NIST-610 & 433 & 421 & 419 & 447 & 431 & 450 & 461 & 441 & 442 & 418 & 444 & 410 & 416 & 434 & 425 & 372 & 451 & 433.1 & 430.0 \\
\hline 91500std & 5.0 & 153 & 0.82 & 2.94 & 0.28 & 0.5 & 0.24 & 2.84 & 1.05 & 12.6 & 5.47 & 28.8 & 7.39 & 77.0 & 14.6 & 5999 & 0.6 & 34.5 & 88 \\
\hline 91500std & 4.8 & 147 & 0.82 & 2.77 & 0.28 & 0.5 & 0.23 & 2.46 & 1.03 & 12.6 & 5.25 & 26.7 & 7.27 & 72.1 & 14.1 & 5820 & 0.5 & 32.9 & 84 \\
\hline 91500std & 4.7 & 145 & 0.77 & 2.59 & 0.28 & 0.5 & 0.20 & 2.56 & 0.97 & 12.9 & 5.14 & 26.7 & 6.91 & 73.7 & 14.1 & 5910 & 0.6 & 31.9 & 83 \\
\hline 91500std & 6.0 & 148 & 0.86 & 2.88 & 0.22 & 0.5 & 0.27 & 2.45 & 1.00 & 12.5 & 5.36 & 26.9 & 7.14 & 74.8 & 14.5 & 5995 & 0.6 & 33.0 & 84 \\
\hline 91500 std & 6.0 & 147 & 0.75 & 2.63 & 0.30 & 0.6 & 0.26 & 2.85 & 1.00 & 12.6 & 5.15 & 27.2 & 7.17 & 73.4 & 14.3 & 5929 & 0.6 & 32.3 & 83 \\
\hline 91500std & 5.5 & 145 & 0.87 & 2.86 & 0.34 & 0.4 & 0.29 & 2.83 & 0.96 & 12.5 & 5.35 & 26.4 & 7.05 & 72.9 & 14.2 & 5952 & 0.6 & 32.0 & 84 \\
\hline 91500std & 5.7 & 152 & 0.86 & 2.65 & 0.30 & 0.6 & 0.31 & 2.35 & 1.00 & 13.1 & 5.56 & 27.8 & 7.46 & 76.8 & 14.7 & 6024 & 0.6 & 33.9 & 88 \\
\hline 91500std & 5.8 & 158 & 0.77 & 2.87 & 0.33 & 0.5 & 0.35 & 2.95 & 1.02 & 13.8 & 5.65 & 29.1 & 7.82 & 80.3 & 15.0 & 6203 & 0.6 & 34.9 & 91 \\
\hline 91500std & 6.4 & 158 & 0.86 & 3.10 & 0.47 & 0.6 & 0.33 & 2.89 & 1.11 & 13.3 & 5.65 & 28.5 & 7.84 & 77.8 & 14.9 & 6045 & 0.6 & 34.2 & 89 \\
\hline 91500std & 2.9 & 155 & 0.80 & 2.90 & 0.20 & 0.7 & 0.29 & 2.98 & 1.06 & 12.4 & 5.68 & 27.8 & 7.55 & 77.4 & 14.9 & 6063 & 0.6 & 35.2 & 89 \\
\hline 91500std & 4.7 & 154 & 0.79 & 2.67 & 0.29 & 0.6 & 0.31 & 2.62 & 0.96 & 13.3 & 5.46 & 28.2 & 7.49 & 75.7 & 14.7 & 6184 & 0.6 & 33.9 & 88 \\
\hline 91500 std & 6.6 & 152 & 0.91 & 2.98 & 0.34 & 0.7 & 0.29 & 2.60 & 1.01 & 13.0 & 5.70 & 27.7 & 7.53 & 77.8 & 15.2 & 6412 & 0.6 & 33.2 & 87 \\
\hline GJ-1 & 3.78 & 219 & 1.53 & 14.7 & 0.40 & 1.51 & 1.01 & 6.7 & 1.86 & 18.8 & 6.26 & 27.8 & 6.44 & 60.6 & 11.4 & 6109 & 0.49 & 8.67 & 284 \\
\hline GJ-1 & 2.91 & 233 & 1.60 & 15.3 & 0.68 & 1.40 & 1.02 & 7.4 & 1.97 & 19.5 & 7.03 & 28.7 & 6.62 & 64.2 & 12.5 & 6579 & 0.46 & 9.22 & 304 \\
\hline
\end{tabular}


Table A3. LA-ICP-MS Lu-Hf isotopic data of standard zircons.

\begin{tabular}{|c|c|c|c|c|c|c|c|c|c|c|c|c|}
\hline \multirow{2}{*}{$\begin{array}{c}\text { Analysis } \\
\text { No. }\end{array}$} & \multirow{2}{*}{$\begin{array}{c}\text { Sample } \\
\text { Name }\end{array}$} & \multicolumn{2}{|c|}{${ }^{176} \mathrm{Hf} /{ }^{177} \mathrm{Hf}$} & \multicolumn{2}{|c|}{${ }^{176} \mathrm{Lu} /{ }^{177} \mathrm{Hf}$} & \multicolumn{2}{|c|}{${ }^{176} \mathrm{Yb} /{ }^{177} \mathrm{Hf}$} & \multirow{2}{*}{$\begin{array}{c}\text { Hf } \\
(\mathrm{ppm})\end{array}$} & \multirow{2}{*}{$\begin{array}{c}\mathrm{Yb} \\
(\mathrm{ppm})\end{array}$} & \multirow{2}{*}{$\begin{array}{c}\mathrm{Lu} \\
(\mathrm{ppm})\end{array}$} & \multirow{2}{*}{$\varepsilon \mathbf{H f}(\mathbf{0})$} & \multirow{2}{*}{10} \\
\hline & & Ratio & $1 \sigma$ & Ratio & $1 \sigma$ & Ratio & $1 \sigma$ & & & & & \\
\hline \multicolumn{13}{|c|}{ Standard Zircon 91500 as an External Standard $\left(\right.$ Reference ${ }^{176} \mathrm{Hf} /{ }^{177} \mathrm{Hf}$ Value $\left.=0.282308 \pm 6,2 \sigma[45]\right)$} \\
\hline JAN14A20 & 91500 & 0.282188 & 0.000027 & 0.000294 & 0.000001 & 0.006999 & 0.000039 & 6234 & 76 & 14 & -20.6 & 1.1 \\
\hline JAN14A28 & 91500 & 0.282408 & 0.000018 & 0.000288 & 0.000001 & 0.006683 & 0.000022 & 8714 & 103 & 19 & -12.9 & 0.8 \\
\hline JAN14A29 & 91500 & 0.282368 & 0.000023 & 0.000286 & 0.000001 & 0.006635 & 0.000034 & 8619 & 101 & 18 & -14.3 & 1.0 \\
\hline JAN14A37 & 91500 & 0.282409 & 0.000031 & 0.000299 & 0.000001 & 0.007099 & 0.000030 & 5832 & 72 & 13 & -12.8 & 1.2 \\
\hline JAN14A46 & 91500 & 0.282490 & 0.000042 & 0.000297 & 0.000001 & 0.006949 & 0.000039 & 6056 & 74 & 13 & -10.0 & 1.6 \\
\hline JAN14A47 & 91500 & 0.282594 & 0.000030 & 0.000286 & 0.000001 & 0.006720 & 0.000041 & 5851 & 70 & 12 & -6.3 & 1.2 \\
\hline JAN14A55 & 91500 & 0.282362 & 0.000033 & 0.000297 & 0.000001 & 0.006890 & 0.000028 & 6470 & 79 & 14 & -14.5 & 1.3 \\
\hline JAN14A56 & 91500 & 0.282591 & 0.000042 & 0.000290 & 0.000001 & 0.006705 & 0.000040 & 4288 & 51 & 9 & -6.4 & 1.6 \\
\hline JAN14A66 & 91500 & 0.282479 & 0.000032 & 0.000280 & 0.000002 & 0.006355 & 0.000066 & 5354 & 62 & 11 & -10.4 & 1.3 \\
\hline JAN14A67 & 91500 & 0.282560 & 0.000024 & 0.000285 & 0.000001 & 0.006649 & 0.000038 & 6252 & 73 & 13 & -7.5 & 1.0 \\
\hline $\begin{array}{c}\text { Average } \\
N=6\end{array}$ & & 0.282441 & 0.000032 & 0.000291 & 0.000001 & 0.006790 & 0.000036 & $76,314.7$ & 914.5442 & 164.9912 & -11.7 & 1.2 \\
\hline JAN14A64 & GJ-1 & 0.282045 & 0.000027 & 0.000259 & 0.000001 & 0.005945 & 0.000035 & 6369 & 66 & 12 & -25.7 & 1.1 \\
\hline JAN14A65 & GJ-1 & 0.282150 & 0.000021 & 0.000260 & 0.000000 & 0.005962 & 0.000019 & 9239 & 96 & 18 & -22.0 & 0.9 \\
\hline $\begin{array}{c}\text { Average } \\
N=2\end{array}$ & & 0.282097 & 0.000024 & 0.000259 & 0.000000 & 0.005953 & 0.000027 & 7804 & 81 & 15 & -23.9 & 1.0 \\
\hline
\end{tabular}

Table A4. LA-ICP-MS zircon U-Pb isotope dating results for samples JS26, JS14-1, and JS14-2 from the Dagushi Gp.

\begin{tabular}{|c|c|c|c|c|c|c|c|c|c|c|c|c|c|c|c|}
\hline \multirow{2}{*}{ Spot No. } & \multirow{2}{*}{$\begin{array}{c}\text { Th } \\
\text { ppm }\end{array}$} & \multirow{2}{*}{$\begin{array}{c}\mathrm{U} \\
\mathrm{ppm}\end{array}$} & \multirow{2}{*}{$\mathrm{Th} / \mathrm{U}$} & \multicolumn{6}{|c|}{ Isotopic Ratios } & \multicolumn{6}{|c|}{ Age (Ma) } \\
\hline & & & & ${ }^{207} \mathrm{~Pb} /{ }^{206} \mathrm{~Pb}$ & $1 \sigma$ & ${ }^{207} \mathrm{~Pb} /{ }^{235} \mathrm{U}$ & $1 \sigma$ & ${ }^{206} \mathrm{~Pb} /{ }^{238} \mathrm{U}$ & $1 \sigma$ & ${ }^{207} \mathrm{~Pb} /{ }^{206} \mathrm{~Pb}$ & $1 \sigma$ & ${ }^{207} \mathrm{~Pb} /{ }^{235} \mathrm{U}$ & $1 \sigma$ & ${ }^{206} \mathrm{~Pb} /{ }^{238} \mathrm{U}$ & $1 \sigma$ \\
\hline \multicolumn{16}{|c|}{ JS26 (Coarse-grained Meta-Quartz Sandstone) } \\
\hline JS26-01 & 176 & 577 & 0.3 & 0.1784 & 0.0023 & 12.9316 & 0.1766 & 0.5230 & 0.0062 & 2639 & 21 & 2675 & 13 & 2712 & 26 \\
\hline JS26-02 & 134 & 322 & 0.4 & 0.1793 & 0.0027 & 12.9745 & 0.2060 & 0.5221 & 0.0065 & 2646 & 25 & 2678 & 15 & 2708 & 27 \\
\hline JS26-03 & 219 & 665 & 0.3 & 0.1793 & 0.0026 & 12.4993 & 0.1858 & 0.5027 & 0.0061 & 2647 & 18 & 2643 & 14 & 2626 & 26 \\
\hline JS26-04 & 364 & 798 & 0.5 & 0.1795 & 0.0029 & 11.8279 & 0.1908 & 0.4743 & 0.0054 & 2650 & 27 & 2591 & 15 & 2502 & 24 \\
\hline JS26-05 & 267 & 843 & 0.3 & 0.1793 & 0.0032 & 12.8253 & 0.2269 & 0.5154 & 0.0064 & 2647 & 29 & 2667 & 17 & 2680 & 27 \\
\hline
\end{tabular}


Table A4. Cont.

\begin{tabular}{|c|c|c|c|c|c|c|c|c|c|c|c|c|c|c|c|}
\hline \multirow{2}{*}{ Spot No. } & \multirow{2}{*}{$\begin{array}{c}\text { Th } \\
\text { ppm }\end{array}$} & \multirow{2}{*}{$\begin{array}{c}\mathrm{U} \\
\mathrm{ppm}\end{array}$} & \multirow{2}{*}{$\mathrm{Th} / \mathrm{U}$} & \multicolumn{6}{|c|}{ Isotopic Ratios } & \multicolumn{6}{|c|}{ Age (Ma) } \\
\hline & & & & ${ }^{207} \mathrm{~Pb} /{ }^{206} \mathrm{~Pb}$ & $1 \sigma$ & ${ }^{207} \mathrm{~Pb} /{ }^{235} \mathrm{U}$ & $1 \sigma$ & ${ }^{206} \mathrm{~Pb} /{ }^{238} \mathrm{U}$ & $1 \sigma$ & ${ }^{207} \mathrm{~Pb} /{ }^{206} \mathrm{~Pb}$ & $1 \sigma$ & ${ }^{207} \mathrm{~Pb} /{ }^{235} \mathrm{U}$ & $1 \sigma$ & ${ }^{206} \mathrm{~Pb} /{ }^{238} \mathrm{U}$ & $1 \sigma$ \\
\hline JS26-06 & 136 & 411 & 0.3 & 0.1825 & 0.0037 & 13.0676 & 0.2632 & 0.5168 & 0.0069 & 2676 & 33 & 2685 & 19 & 2685 & 29 \\
\hline JS26-07 & 291 & 721 & 0.4 & 0.1767 & 0.0035 & 12.5000 & 0.2572 & 0.5085 & 0.0068 & 2622 & 32 & 2643 & 19 & 2650 & 29 \\
\hline JS26-08 & 84.8 & 239 & 0.4 & 0.1975 & 0.0040 & 14.0721 & 0.2982 & 0.5130 & 0.0069 & 2805 & 33 & 2755 & 20 & 2670 & 29 \\
\hline JS26-09 & 206 & 579 & 0.4 & 0.1803 & 0.0033 & 13.3069 & 0.2550 & 0.5321 & 0.0074 & 2655 & 31 & 2702 & 18 & 2750 & 31 \\
\hline JS26-10 & 79.2 & 212 & 0.4 & 0.1825 & 0.0037 & 13.0914 & 0.2671 & 0.5178 & 0.0070 & 2676 & 33 & 2686 & 19 & 2690 & 30 \\
\hline JS26-11 & 116 & 93.9 & 1.2 & 0.2099 & 0.0049 & 16.3923 & 0.3844 & 0.5655 & 0.0081 & 2905 & 38 & 2900 & 22 & 2889 & 33 \\
\hline JS26-12 & 152 & 450 & 0.3 & 0.1788 & 0.0037 & 12.9467 & 0.2666 & 0.5222 & 0.0066 & 2643 & 34 & 2676 & 19 & 2708 & 28 \\
\hline JS26-13 & 163 & 364 & 0.4 & 0.1833 & 0.0038 & 13.3961 & 0.2850 & 0.5265 & 0.0069 & 2682 & 34 & 2708 & 20 & 2727 & 29 \\
\hline JS26-14 & 173 & 286 & 0.6 & 0.1610 & 0.0033 & 10.7773 & 0.2255 & 0.4824 & 0.0063 & 2466 & 34 & 2504 & 19 & 2538 & 28 \\
\hline JS26-15 & 58.1 & 126 & 0.5 & 0.1876 & 0.0041 & 14.0461 & 0.3182 & 0.5405 & 0.0075 & 2721 & 36 & 2753 & 21 & 2786 & 31 \\
\hline JS26-16 & 220 & 633 & 0.3 & 0.1926 & 0.0034 & 14.5333 & 0.2636 & 0.5428 & 0.0068 & 2764 & 30 & 2785 & 17 & 2795 & 28 \\
\hline JS26-17 & 303 & 654 & 0.5 & 0.1802 & 0.0034 & 13.1500 & 0.2496 & 0.5250 & 0.0067 & 2655 & 32 & 2690 & 18 & 2721 & 28 \\
\hline JS26-18 & 20.7 & 54.7 & 0.4 & 0.2136 & 0.0060 & 16.6589 & 0.4684 & 0.5654 & 0.0096 & 3000 & 51 & 2915 & 27 & 2889 & 39 \\
\hline JS26-19 & 282 & 478 & 0.6 & 0.1267 & 0.0027 & 6.7070 & 0.1430 & 0.3812 & 0.0051 & 2054 & 43 & 2074 & 19 & 2082 & 24 \\
\hline JS26-20 & 127 & 401 & 0.3 & 0.1774 & 0.0035 & 12.9068 & 0.2590 & 0.5238 & 0.0069 & 2629 & 32 & 2673 & 19 & 2715 & 29 \\
\hline JS26-21 & 222 & 520 & 0.4 & 0.1774 & 0.0032 & 12.3463 & 0.2207 & 0.5015 & 0.0060 & 2629 & 30 & 2631 & 17 & 2620 & 26 \\
\hline JS26-22 & 98.9 & 234 & 0.4 & 0.2039 & 0.0040 & 15.5934 & 0.3216 & 0.5519 & 0.0075 & 2858 & 32 & 2852 & 20 & 2833 & 31 \\
\hline JS26-24 & 163 & 531 & 0.3 & 0.1764 & 0.0035 & 12.7515 & 0.2628 & 0.5218 & 0.0068 & 2619 & 33 & 2661 & 19 & 2707 & 29 \\
\hline JS26-25 & 106 & 330 & 0.3 & 0.1788 & 0.0037 & 13.0864 & 0.2782 & 0.5296 & 0.0071 & 2643 & 34 & 2686 & 20 & 2740 & 30 \\
\hline JS26-26 & 332 & 552 & 0.6 & 0.1244 & 0.0026 & 6.5617 & 0.1395 & 0.3822 & 0.0052 & 2020 & 37 & 2054 & 19 & 2086 & 24 \\
\hline JS26-27 & 245 & 766 & 0.3 & 0.1747 & 0.0030 & 12.8268 & 0.2303 & 0.5306 & 0.0066 & 2603 & 29 & 2667 & 17 & 2744 & 28 \\
\hline JS26-28 & 131 & 163 & 0.8 & 0.1802 & 0.0037 & 12.8929 & 0.2792 & 0.5178 & 0.0070 & 2654 & 34 & 2672 & 20 & 2690 & 30 \\
\hline JS26-29 & 245 & 770 & 0.3 & 0.1779 & 0.0031 & 13.1151 & 0.2402 & 0.5324 & 0.0066 & 2635 & 28 & 2688 & 17 & 2752 & 28 \\
\hline JS26-30 & 124 & 458 & 0.3 & 0.1763 & 0.0033 & 12.5621 & 0.2429 & 0.5152 & 0.0066 & 2620 & 31 & 2647 & 18 & 2679 & 28 \\
\hline JS26-31 & 157 & 464 & 0.3 & 0.1751 & 0.0035 & 12.6265 & 0.2644 & 0.5209 & 0.0068 & 2606 & 33 & 2652 & 20 & 2703 & 29 \\
\hline JS26-32 & 149 & 431 & 0.3 & 0.1772 & 0.0034 & 12.8077 & 0.2474 & 0.5229 & 0.0067 & 2627 & 32 & 2666 & 18 & 2711 & 28 \\
\hline JS26-33 & 209 & 705 & 0.3 & 0.1759 & 0.0030 & 12.7158 & 0.2308 & 0.5223 & 0.0066 & 2615 & 28 & 2659 & 17 & 2709 & 28 \\
\hline JS26-34 & 71.3 & 149 & 0.5 & 0.1581 & 0.0036 & 10.3641 & 0.2466 & 0.4750 & 0.0067 & 2435 & 39 & 2468 & 22 & 2505 & 29 \\
\hline JS26-35 & 163 & 106 & 1.5 & 0.1409 & 0.0038 & 7.9153 & 0.2171 & 0.4079 & 0.0060 & 2239 & 47 & 2221 & 25 & 2205 & 27 \\
\hline JS26-36 & 120 & 193 & 0.6 & 0.1919 & 0.0043 & 13.6799 & 0.3137 & 0.5161 & 0.0068 & 2758 & 37 & 2728 & 22 & 2682 & 29 \\
\hline JS26-37 & 28.8 & 73.1 & 0.4 & 0.1841 & 0.0051 & 13.0671 & 0.3689 & 0.5154 & 0.0083 & 2690 & 45 & 2685 & 27 & 2680 & 35 \\
\hline JS26-38 & 305 & 511 & 0.6 & 0.1819 & 0.0034 & 13.5033 & 0.2601 & 0.5354 & 0.0068 & 2670 & 32 & 2716 & 18 & 2764 & 28 \\
\hline
\end{tabular}


Table A4. Cont.

\begin{tabular}{|c|c|c|c|c|c|c|c|c|c|c|c|c|c|c|c|}
\hline \multirow{2}{*}{ Spot No. } & \multirow{2}{*}{$\begin{array}{c}\text { Th } \\
\text { ppm }\end{array}$} & \multirow{2}{*}{$\frac{\mathrm{U}}{\mathrm{ppm}}$} & \multirow{2}{*}{$\mathrm{Th} / \mathrm{U}$} & \multicolumn{6}{|c|}{ Isotopic Ratios } & \multicolumn{6}{|c|}{ Age (Ma) } \\
\hline & & & & ${ }^{207} \mathrm{~Pb} / 206 \mathrm{~Pb}$ & $1 \sigma$ & ${ }^{207} \mathrm{~Pb} /{ }^{235} \mathrm{U}$ & $1 \sigma$ & ${ }^{206} \mathrm{~Pb} /{ }^{238} \mathrm{U}$ & $1 \sigma$ & ${ }^{207} \mathrm{~Pb} /{ }^{206} \mathrm{~Pb}$ & $1 \sigma$ & ${ }^{207} \mathrm{~Pb} /{ }^{235} \mathrm{U}$ & $1 \sigma$ & ${ }^{206} \mathrm{~Pb} /{ }^{238} \mathrm{U}$ & $1 \sigma$ \\
\hline JS26-39 & 92.9 & 246 & 0.4 & 0.1782 & 0.0035 & 13.4623 & 0.2768 & 0.5452 & 0.0077 & 2637 & 33 & 2713 & 19 & 2805 & 32 \\
\hline JS26-40 & 184 & 144 & 1.3 & 0.1177 & 0.0031 & 6.1196 & 0.1656 & 0.3750 & 0.0055 & 1921 & 48 & 1993 & 24 & 2053 & 26 \\
\hline JS26-41 & 140 & 443 & 0.3 & 0.1739 & 0.0034 & 12.6780 & 0.2558 & 0.5237 & 0.0069 & 2595 & 32 & 2656 & 19 & 2715 & 29 \\
\hline JS26-42 & 113 & 234 & 0.5 & 0.1733 & 0.0039 & 12.3381 & 0.2739 & 0.5126 & 0.0071 & 2590 & 37 & 2630 & 21 & 2668 & 30 \\
\hline JS26-43 & 114 & 291 & 0.4 & 0.1734 & 0.0037 & 12.5839 & 0.2677 & 0.5226 & 0.0072 & 2590 & 37 & 2649 & 20 & 2710 & 31 \\
\hline JS26-44 & 215 & 459 & 0.5 & 0.2063 & 0.0039 & 17.5716 & 0.3461 & 0.6117 & 0.0081 & 2877 & 31 & 2967 & 19 & 3077 & 33 \\
\hline JS26-45 & 169 & 466 & 0.4 & 0.1778 & 0.0033 & 13.0506 & 0.2463 & 0.5283 & 0.0069 & 2632 & 32 & 2683 & 18 & 2734 & 29 \\
\hline JS26-46 & 256 & 740 & 0.3 & 0.1737 & 0.0031 & 12.4875 & 0.2300 & 0.5173 & 0.0067 & 2594 & 29 & 2642 & 17 & 2688 & 28 \\
\hline JS26-47 & 11.8 & 50.3 & 0.2 & 0.2049 & 0.0060 & 15.3118 & 0.4507 & 0.5458 & 0.0095 & 2866 & 48 & 2835 & 28 & 2808 & 40 \\
\hline JS26-48 & 167 & 490 & 0.3 & 0.1739 & 0.0035 & 12.5055 & 0.2574 & 0.5184 & 0.0068 & 2595 & 33 & 2643 & 19 & 2692 & 29 \\
\hline JS26-49 & 128 & 345 & 0.4 & 0.1770 & 0.0037 & 12.8091 & 0.2722 & 0.5227 & 0.0071 & 2625 & 35 & 2666 & 20 & 2711 & 30 \\
\hline JS26-50 & 130 & 169 & 0.8 & 0.1803 & 0.0039 & 12.3890 & 0.2603 & 0.4979 & 0.0068 & 2657 & 36 & 2634 & 20 & 2605 & 29 \\
\hline JS26-51 & 268 & 348 & 0.8 & 0.2174 & 0.0037 & 17.9769 & 0.3200 & 0.5966 & 0.0077 & 2961 & -6 & 2989 & 17 & 3016 & 31 \\
\hline JS26-52 & 291 & 493 & 0.6 & 0.1905 & 0.0030 & 12.8817 & 0.2397 & 0.4876 & 0.0075 & 2747 & 26 & 2671 & 18 & 2560 & 32 \\
\hline JS26-53 & 191 & 478 & 0.4 & 0.1488 & 0.0022 & 9.2644 & 0.1427 & 0.4491 & 0.0054 & 2332 & 26 & 2364 & 14 & 2391 & 24 \\
\hline JS26-54 & 225 & 577 & 0.4 & 0.1813 & 0.0024 & 12.9805 & 0.1833 & 0.5161 & 0.0064 & 2665 & 22 & 2678 & 13 & 2683 & 27 \\
\hline JS26-55 & 162 & 435 & 0.4 & 0.1790 & 0.0024 & 12.6378 & 0.1818 & 0.5088 & 0.0063 & 2644 & 23 & 2653 & 14 & 2651 & 27 \\
\hline JS26-57 & 92.1 & 129 & 0.7 & 0.1147 & 0.0031 & 5.2414 & 0.1444 & 0.3317 & 0.0047 & 1876 & 49 & 1859 & 24 & 1846 & 23 \\
\hline JS26-58 & 103 & 245 & 0.4 & 0.2050 & 0.0029 & 15.4939 & 0.2221 & 0.5447 & 0.0064 & 2866 & 28 & 2846 & 14 & 2803 & 27 \\
\hline JS26-59 & 182 & 368 & 0.5 & 0.1998 & 0.0028 & 14.9607 & 0.2302 & 0.5395 & 0.0069 & 2824 & 23 & 2813 & 15 & 2781 & 29 \\
\hline JS26-60 & 86.2 & 184 & 0.5 & 0.1788 & 0.0028 & 12.3345 & 0.2047 & 0.4972 & 0.0065 & 2642 & 25 & 2630 & 16 & 2602 & 28 \\
\hline \multicolumn{16}{|c|}{ JS14-1 (Medium-coarse-grained Meta-quartz Sandstone) } \\
\hline JS14-1-01 & 567 & 271 & 2.1 & 0.1508 & 0.0023 & 8.8459 & 0.1386 & 0.4243 & 0.0055 & 2355 & 26 & 2322 & 14 & 2280 & 25 \\
\hline JS14-1-02 & 112 & 188 & 0.6 & 0.0957 & 0.0022 & 3.8223 & 0.0882 & 0.2889 & 0.0038 & 1543 & 43 & 1597 & 19 & 1636 & 19 \\
\hline JS14-1-03 & 317 & 447 & 0.7 & 0.0975 & 0.0017 & 3.5198 & 0.0626 & 0.2606 & 0.0032 & 1577 & 33 & 1532 & 14 & 1493 & 16 \\
\hline JS14-1-04 & 425 & 787 & 0.5 & 0.0949 & 0.0016 & 3.6276 & 0.0635 & 0.2756 & 0.0034 & 1528 & 32 & 1556 & 14 & 1569 & 17 \\
\hline JS14-1-05 & 170 & 330 & 0.5 & 0.1764 & 0.0031 & 12.3465 & 0.2224 & 0.5046 & 0.0064 & 2620 & 30 & 2631 & 17 & 2634 & 27 \\
\hline JS14-1-06 & 128 & 330 & 0.4 & 0.1773 & 0.0034 & 12.4306 & 0.2440 & 0.5057 & 0.0066 & 2627 & 32 & 2637 & 18 & 2638 & 28 \\
\hline JS14-1-07 & 258 & 313 & 0.8 & 0.0950 & 0.0021 & 3.6545 & 0.0855 & 0.2776 & 0.0039 & 1529 & 43 & 1561 & 19 & 1579 & 20 \\
\hline JS14-1-08 & 186 & 456 & 0.4 & 0.1354 & 0.0023 & 7.7327 & 0.1367 & 0.4120 & 0.0054 & 2169 & 30 & 2200 & 16 & 2224 & 25 \\
\hline JS14-1-09 & 278 & 394 & 0.7 & 0.0985 & 0.0018 & 3.7681 & 0.0705 & 0.2768 & 0.0036 & 1595 & 34 & 1586 & 15 & 1575 & 18 \\
\hline JS14-1-10 & 329 & 922 & 0.4 & 0.1788 & 0.0024 & 12.4490 & 0.1788 & 0.5018 & 0.0061 & 2643 & 22 & 2639 & 13 & 2621 & 26 \\
\hline
\end{tabular}


Table A4. Cont.

\begin{tabular}{|c|c|c|c|c|c|c|c|c|c|c|c|c|c|c|c|}
\hline \multirow{2}{*}{ Spot No. } & \multirow{2}{*}{$\begin{array}{c}\text { Th } \\
\text { ppm }\end{array}$} & \multirow{2}{*}{$\frac{\mathrm{U}}{\mathrm{ppm}}$} & \multirow{2}{*}{$\mathrm{Th} / \mathrm{U}$} & \multicolumn{6}{|c|}{ Isotopic Ratios } & \multicolumn{6}{|c|}{ Age (Ma) } \\
\hline & & & & ${ }^{207} \mathrm{~Pb} /{ }^{206} \mathrm{~Pb}$ & $1 \sigma$ & ${ }^{207} \mathrm{~Pb} /{ }^{235} \mathrm{U}$ & $1 \sigma$ & ${ }^{206} \mathrm{~Pb} /{ }^{238} \mathrm{U}$ & $1 \sigma$ & ${ }^{207} \mathrm{~Pb} /{ }^{206} \mathrm{~Pb}$ & $1 \sigma$ & ${ }^{207} \mathrm{~Pb} /{ }^{235} \mathrm{U}$ & $1 \sigma$ & ${ }^{206} \mathrm{~Pb} /{ }^{238} \mathrm{U}$ & 10 \\
\hline JS14-1-11 & 201 & 501 & 0.4 & 0.2036 & 0.0026 & 15.5242 & 0.2131 & 0.5501 & 0.0066 & 2855 & 21 & 2848 & 13 & 2826 & 27 \\
\hline JS14-1-12 & 397 & 577 & 0.7 & 0.0987 & 0.0015 & 3.7787 & 0.0588 & 0.2765 & 0.0034 & 1600 & 28 & 1588 & 13 & 1574 & 17 \\
\hline JS14-1-13 & 134 & 661 & 0.2 & 0.1133 & 0.0016 & 5.2247 & 0.0817 & 0.3324 & 0.0040 & 1854 & 26 & 1857 & 13 & 1850 & 19 \\
\hline JS14-1-14 & 165 & 281 & 0.6 & 0.1026 & 0.0021 & 3.8971 & 0.0815 & 0.2745 & 0.0035 & 1672 & 38 & 1613 & 17 & 1563 & 17 \\
\hline JS14-1-15 & 164 & 287 & 0.6 & 0.1000 & 0.0022 & 3.8973 & 0.0880 & 0.2815 & 0.0037 & 1625 & 41 & 1613 & 18 & 1599 & 19 \\
\hline JS14-1-16 & 146 & 218 & 0.7 & 0.2533 & 0.0044 & 22.2843 & 0.4101 & 0.6345 & 0.0081 & 3205 & 28 & 3196 & 18 & 3167 & 32 \\
\hline JS14-1-17 & 147 & 289 & 0.5 & 0.1003 & 0.0023 & 3.8694 & 0.0889 & 0.2795 & 0.0038 & 1631 & 43 & 1607 & 19 & 1589 & 19 \\
\hline JS14-1-18 & 333 & 653 & 0.5 & 0.1001 & 0.0022 & 3.9440 & 0.0880 & 0.2847 & 0.0038 & 1628 & 40 & 1623 & 18 & 1615 & 19 \\
\hline JS14-1-19 & 369 & 489 & 0.8 & 0.0912 & 0.0021 & 3.0993 & 0.0735 & 0.2450 & 0.0032 & 1451 & 44 & 1433 & 18 & 1413 & 17 \\
\hline JS14-1-20 & 114 & 267 & 0.4 & 0.1862 & 0.0036 & 13.3860 & 0.2705 & 0.5195 & 0.0069 & 2708 & 32 & 2707 & 19 & 2697 & 29 \\
\hline JS14-1-21 & 197 & 376 & 0.5 & 0.1386 & 0.0028 & 7.6630 & 0.1629 & 0.3995 & 0.0053 & 2210 & 40 & 2192 & 19 & 2167 & 24 \\
\hline JS14-1-22 & 100 & 178 & 0.6 & 0.0992 & 0.0025 & 3.8195 & 0.1010 & 0.2792 & 0.0039 & 1610 & 48 & 1597 & 21 & 1587 & 20 \\
\hline JS14-1-23 & 616 & 611 & 1.0 & 0.2005 & 0.0036 & 13.6012 & 0.2520 & 0.4899 & 0.0060 & 2831 & -4 & 2722 & 18 & 2570 & 26 \\
\hline JS14-1-24 & 275 & 253 & 1.1 & 0.1004 & 0.0024 & 3.9944 & 0.0959 & 0.2885 & 0.0040 & 1631 & 44 & 1633 & 20 & 1634 & 20 \\
\hline JS14-1-25 & 439 & 450 & 1.0 & 0.1012 & 0.0023 & 3.7954 & 0.0895 & 0.2716 & 0.0038 & 1656 & 42 & 1592 & 19 & 1549 & 19 \\
\hline JS14-1-26 & 126 & 191 & 0.7 & 0.1029 & 0.0028 & 4.0177 & 0.1147 & 0.2834 & 0.0042 & 1677 & 51 & 1638 & 23 & 1608 & 21 \\
\hline JS14-1-27 & 187 & 363 & 0.5 & 0.2024 & 0.0036 & 15.8306 & 0.3049 & 0.5653 & 0.0076 & 2846 & 30 & 2867 & 18 & 2888 & 31 \\
\hline JS14-1-29 & 141 & 205 & 0.7 & 0.2033 & 0.0038 & 15.6861 & 0.3137 & 0.5591 & 0.0079 & 2853 & 31 & 2858 & 19 & 2863 & 33 \\
\hline JS14-1-30 & 301 & 478 & 0.6 & 0.0968 & 0.0020 & 3.8143 & 0.0806 & 0.2853 & 0.0037 & 1563 & 238 & 1596 & 17 & 1618 & 19 \\
\hline JS14-1-31 & 78.2 & 184 & 0.4 & 0.1008 & 0.0026 & 3.9819 & 0.1101 & 0.2858 & 0.0042 & 1639 & 48 & 1631 & 22 & 1620 & 21 \\
\hline JS14-1-32 & 419 & 607 & 0.7 & 0.0970 & 0.0019 & 3.7122 & 0.0755 & 0.2770 & 0.0037 & 1566 & 37 & 1574 & 16 & 1576 & 18 \\
\hline JS14-1-33 & 93.1 & 160 & 0.6 & 0.1016 & 0.0027 & 3.8868 & 0.1061 & 0.2779 & 0.0040 & 1654 & 50 & 1611 & 22 & 1581 & 20 \\
\hline JS14-1-34 & 662 & 620 & 1.1 & 0.0996 & 0.0019 & 3.6683 & 0.0725 & 0.2663 & 0.0035 & 1617 & 37 & 1564 & 16 & 1522 & 18 \\
\hline JS14-1-35 & 254 & 609 & 0.4 & 0.1623 & 0.0029 & 10.3763 & 0.1953 & 0.4617 & 0.0059 & 2479 & 30 & 2469 & 17 & 2447 & 26 \\
\hline JS14-1-37 & 580 & 858 & 0.7 & 0.1400 & 0.0027 & 7.4575 & 0.1585 & 0.3837 & 0.0054 & 2227 & 33 & 2168 & 19 & 2094 & 25 \\
\hline JS14-1-38 & 212 & 365 & 0.6 & 0.0996 & 0.0021 & 3.8566 & 0.0820 & 0.2796 & 0.0037 & 1617 & 39 & 1605 & 17 & 1589 & 19 \\
\hline JS14-1-39 & 178 & 453 & 0.4 & 0.1914 & 0.0030 & 13.3165 & 0.2171 & 0.5016 & 0.0061 & 2754 & 26 & 2702 & 15 & 2621 & 26 \\
\hline JS14-1-40 & 195 & 432 & 0.5 & 0.1919 & 0.0028 & 13.7623 & 0.2093 & 0.5171 & 0.0063 & 2758 & 25 & 2733 & 14 & 2687 & 27 \\
\hline JS14-1-41 & 361 & 815 & 0.4 & 0.1798 & 0.0022 & 12.6775 & 0.1773 & 0.5082 & 0.0066 & 2652 & 20 & 2656 & 13 & 2649 & 28 \\
\hline JS14-1-42 & 478 & 574 & 0.8 & 0.0971 & 0.0014 & 3.8071 & 0.0640 & 0.2820 & 0.0035 & 1569 & 28 & 1594 & 14 & 1602 & 17 \\
\hline JS14-1-43 & 86.0 & 155 & 0.6 & 0.1018 & 0.0025 & 4.0389 & 0.1033 & 0.2872 & 0.0041 & 1658 & 46 & 1642 & 21 & 1628 & 20 \\
\hline JS14-1-44 & 231 & 275 & 0.8 & 0.0992 & 0.0019 & 3.8168 & 0.0773 & 0.2777 & 0.0037 & 1610 & 41 & 1596 & 16 & 1580 & 19 \\
\hline JS14-1-45 & 110 & 284 & 0.4 & 0.1006 & 0.0019 & 3.9248 & 0.0772 & 0.2819 & 0.0037 & 1635 & 36 & 1619 & 16 & 1601 & 18 \\
\hline JS14-1-46 & 124 & 232 & 0.5 & 0.1000 & 0.0024 & 3.9205 & 0.0958 & 0.2832 & 0.0039 & 1633 & 44 & 1618 & 20 & 1607 & 20 \\
\hline
\end{tabular}


Table A4. Cont.

\begin{tabular}{|c|c|c|c|c|c|c|c|c|c|c|c|c|c|c|c|}
\hline \multirow{2}{*}{ Spot No. } & \multirow{2}{*}{$\begin{array}{c}\text { Th } \\
\text { ppm }\end{array}$} & \multirow{2}{*}{$\begin{array}{c}\mathrm{U} \\
\mathrm{ppm}\end{array}$} & \multirow{2}{*}{$\mathrm{Th} / \mathrm{U}$} & \multicolumn{6}{|c|}{ Isotopic Ratios } & \multicolumn{6}{|c|}{ Age (Ma) } \\
\hline & & & & ${ }^{207} \mathrm{~Pb} /{ }^{206} \mathrm{~Pb}$ & $1 \sigma$ & ${ }^{207} \mathrm{~Pb} /{ }^{235} \mathrm{U}$ & $1 \sigma$ & ${ }^{206} \mathrm{~Pb} /{ }^{238} \mathrm{U}$ & $1 \sigma$ & ${ }^{207} \mathrm{~Pb} /{ }^{206} \mathrm{~Pb}$ & $1 \sigma$ & ${ }^{207} \mathrm{~Pb} /{ }^{235} \mathrm{U}$ & $1 \sigma$ & ${ }^{206} \mathrm{~Pb} /{ }^{238} \mathrm{U}$ & 10 \\
\hline JS14-1-47 & 187 & 331 & 0.6 & 0.1030 & 0.0022 & 3.9315 & 0.0864 & 0.2762 & 0.0037 & 1680 & 39 & 1620 & 18 & 1572 & 19 \\
\hline JS14-1-48 & 221 & 537 & 0.4 & 0.1813 & 0.0035 & 12.6261 & 0.2520 & 0.5019 & 0.0066 & 2665 & 33 & 2652 & 19 & 2622 & 28 \\
\hline JS14-1-49 & 124 & 309 & 0.4 & 0.1359 & 0.0029 & 7.3882 & 0.1619 & 0.3922 & 0.0051 & 2176 & 37 & 2160 & 20 & 2133 & 24 \\
\hline JS14-1-50 & 417 & 797 & 0.5 & 0.1008 & 0.0019 & 3.8209 & 0.0756 & 0.2734 & 0.0035 & 1639 & 35 & 1597 & 16 & 1558 & 17 \\
\hline JS14-1-51 & 541 & 821 & 0.7 & 0.1237 & 0.0022 & 5.9527 & 0.1217 & 0.3464 & 0.0048 & 2010 & 33 & 1969 & 18 & 1917 & 23 \\
\hline JS14-1-52 & 1976 & 1305 & 1.5 & 0.1380 & 0.0024 & 6.2957 & 0.1176 & 0.3292 & 0.0046 & 2203 & 30 & 2018 & 16 & 1834 & 22 \\
\hline JS14-1-53 & 282 & 399 & 0.7 & 0.0997 & 0.0022 & 3.7646 & 0.0833 & 0.2733 & 0.0038 & 1620 & 42 & 1585 & 18 & 1558 & 19 \\
\hline JS14-1-54 & 127 & 369 & 0.3 & 0.1827 & 0.0037 & 12.9191 & 0.2673 & 0.5101 & 0.0067 & 2680 & 33 & 2674 & 20 & 2657 & 28 \\
\hline JS14-1-56 & 779 & 1436 & 0.5 & 0.0991 & 0.0019 & 3.7319 & 0.0747 & 0.2714 & 0.0034 & 1609 & 36 & 1578 & 16 & 1548 & 17 \\
\hline JS14-1-57 & 471 & 562 & 0.8 & 0.0995 & 0.0020 & 3.8234 & 0.0798 & 0.2771 & 0.0036 & 1617 & 38 & 1598 & 17 & 1577 & 18 \\
\hline JS14-1-58 & 2674 & 1198 & 2.2 & 0.0977 & 0.0019 & 3.0563 & 0.0649 & 0.2256 & 0.0033 & 1581 & 36 & 1422 & 16 & 1311 & 17 \\
\hline JS14-1-59 & 160 & 324 & 0.5 & 0.1350 & 0.0026 & 7.2039 & 0.1438 & 0.3852 & 0.0053 & 2165 & 33 & 2137 & 18 & 2100 & 25 \\
\hline JS14-1-60 & 388 & 499 & 0.8 & 0.0992 & 0.0019 & 3.8732 & 0.0805 & 0.2813 & 0.0037 & 1609 & 42 & 1608 & 17 & 1598 & 19 \\
\hline JS14-1-61 & 242 & 246 & 1.0 & 0.1216 & 0.0028 & 6.1767 & 0.1459 & 0.3658 & 0.0049 & 1981 & 41 & 2001 & 21 & 2010 & 23 \\
\hline JS14-1-62 & 217 & 383 & 0.6 & 0.0987 & 0.0024 & 3.9299 & 0.0950 & 0.2873 & 0.0038 & 2000 & 51 & 1620 & 20 & 1628 & 19 \\
\hline JS14-1-63 & 289 & 378 & 0.8 & 0.1013 & 0.0026 & 3.9147 & 0.0994 & 0.2783 & 0.0039 & 1648 & 48 & 1617 & 21 & 1583 & 19 \\
\hline JS14-1-64 & 70.3 & 106 & 0.7 & 0.1893 & 0.0049 & 13.7514 & 0.3560 & 0.5226 & 0.0076 & 2737 & 48 & 2733 & 25 & 2710 & 32 \\
\hline JS14-1-66 & 116 & 195 & 0.6 & 0.0995 & 0.0027 & 4.0719 & 0.1109 & 0.2950 & 0.0044 & 1617 & 50 & 1649 & 22 & 1666 & 22 \\
\hline JS14-1-67 & 358 & 422 & 0.86 & 0.0987 & 0.0023 & 3.8628 & 0.0893 & 0.2809 & 0.0036 & 2000 & 38 & 1606 & 19 & 1596 & 18 \\
\hline JS14-1-68 & 396 & 482 & 0.86 & 0.1007 & 0.0024 & 3.9829 & 0.0926 & 0.2844 & 0.0037 & 1639 & 43 & 1631 & 19 & 1614 & 19 \\
\hline JS14-1-69 & 164 & 461 & 0.4 & 0.1851 & 0.0042 & 13.4459 & 0.3149 & 0.5215 & 0.0073 & 2700 & 38 & 2711 & 22 & 2705 & 31 \\
\hline JS14-1-70 & 113 & 272 & 0.4 & 0.2159 & 0.0052 & 16.9700 & 0.4043 & 0.5652 & 0.0077 & 2950 & 39 & 2933 & 23 & 2888 & 32 \\
\hline JS14-1-71 & 214 & 410 & 0.5 & 0.0981 & 0.0024 & 3.8689 & 0.0953 & 0.2833 & 0.0038 & 1588 & 45 & 1607 & 20 & 1608 & 19 \\
\hline JS14-1-72 & 1193 & 858 & 1.4 & 0.0982 & 0.0021 & 3.8954 & 0.0849 & 0.2847 & 0.0038 & 1591 & 41 & 1613 & 18 & 1615 & 19 \\
\hline JS14-1-73 & 164 & 424 & 0.4 & 0.1852 & 0.0038 & 13.4894 & 0.2754 & 0.5229 & 0.0065 & 2702 & 33 & 2715 & 19 & 2711 & 28 \\
\hline JS14-1-74 & 239 & 601 & 0.4 & 0.1807 & 0.0035 & 12.8931 & 0.2617 & 0.5124 & 0.0070 & 2659 & 31 & 2672 & 19 & 2667 & 30 \\
\hline JS14-1-75 & 111 & 205 & 0.5 & 0.0985 & 0.0029 & 3.8368 & 0.1107 & 0.2820 & 0.0039 & 1595 & 56 & 1601 & 23 & 1601 & 20 \\
\hline \multicolumn{16}{|c|}{ JS14-2 (Medium-coarse-grained Meta-quartz Sandstone) } \\
\hline JS14-2-1 & 152 & 484 & 0.3 & 0.1316 & 0.0017 & 6.6251 & 0.1102 & 0.3617 & 0.0041 & 2120 & 22 & 2063 & 15 & 1990 & 20 \\
\hline JS14-2-2 & 137 & 67 & 2.1 & 0.1006 & 0.0021 & 3.9675 & 0.0812 & 0.2856 & 0.0034 & 1635 & 37 & 1628 & 17 & 1620 & 17 \\
\hline JS14-2-3 & 18 & 72 & 0.2 & 0.1479 & 0.0027 & 9.0198 & 0.1745 & 0.4388 & 0.0046 & 2321 & 31 & 2340 & 18 & 2345 & 21 \\
\hline JS14-2-4 & 84 & 98 & 0.9 & 0.0995 & 0.0019 & 3.9210 & 0.0735 & 0.2841 & 0.0029 & 1617 & 35 & 1618 & 15 & 1612 & 15 \\
\hline
\end{tabular}


Table A4. Cont.

\begin{tabular}{|c|c|c|c|c|c|c|c|c|c|c|c|c|c|c|c|}
\hline \multirow{2}{*}{ Spot No. } & \multirow{2}{*}{$\begin{array}{c}\text { Th } \\
\text { ppm }\end{array}$} & \multirow{2}{*}{$\frac{\mathrm{U}}{\mathrm{ppm}}$} & \multirow{2}{*}{ Th/U } & \multicolumn{6}{|c|}{ Isotopic Ratios } & \multicolumn{6}{|c|}{ Age (Ma) } \\
\hline & & & & ${ }^{207} \mathrm{~Pb} /{ }^{206} \mathrm{~Pb}$ & $1 \sigma$ & ${ }^{207} \mathrm{~Pb} /{ }^{235} \mathrm{U}$ & $1 \sigma$ & ${ }^{206} \mathrm{~Pb} /{ }^{238} \mathrm{U}$ & $1 \sigma$ & ${ }^{207} \mathrm{~Pb} /{ }^{206} \mathrm{~Pb}$ & $1 \sigma$ & ${ }^{207} \mathrm{~Pb} /{ }^{235} \mathrm{U}$ & $1 \sigma$ & ${ }^{206} \mathrm{~Pb} /{ }^{238} \mathrm{U}$ & 10 \\
\hline JS14-2-5 & 89 & 148 & 0.6 & 0.0978 & 0.0018 & 3.8619 & 0.0728 & 0.2843 & 0.0030 & 1583 & 35 & 1606 & 15 & 1613 & 15 \\
\hline JS14-2-6 & 46 & 81 & 0.6 & 0.1881 & 0.0034 & 13.9450 & 0.2581 & 0.5336 & 0.0063 & 2725 & 30 & 2746 & 18 & 2756 & 26 \\
\hline JS14-2-7 & 184 & 190 & 1.0 & 0.1412 & 0.0024 & 8.1466 & 0.1448 & 0.4151 & 0.0050 & 2243 & 30 & 2247 & 16 & 2238 & 23 \\
\hline JS14-2-8 & 236 & 165 & 1.4 & 0.1953 & 0.0029 & 13.5167 & 0.2064 & 0.4969 & 0.0042 & 2787 & 24 & 2716 & 15 & 2600 & 18 \\
\hline JS14-2-9 & 48 & 86 & 0.6 & 0.1018 & 0.0020 & 3.9292 & 0.0818 & 0.2785 & 0.0030 & 1657 & 37 & 1620 & 17 & 1584 & 15 \\
\hline JS14-2-10 & 168 & 225 & 0.7 & 0.1352 & 0.0020 & 7.4124 & 0.1319 & 0.3942 & 0.0045 & 2169 & 25 & 2162 & 16 & 2142 & 21 \\
\hline JS14-2-11 & 130 & 224 & 0.6 & 0.1776 & 0.0026 & 12.0654 & 0.1906 & 0.4900 & 0.0044 & 2631 & 25 & 2610 & 15 & 2571 & 19 \\
\hline JS14-2-12 & 80 & 102 & 0.8 & 0.0994 & 0.0021 & 3.9278 & 0.0861 & 0.2859 & 0.0031 & 1613 & 39 & 1619 & 18 & 1621 & 15 \\
\hline JS14-2-13 & 114 & 131 & 0.9 & 0.0976 & 0.0020 & 3.8802 & 0.0836 & 0.2878 & 0.0030 & 1589 & 38 & 1610 & 17 & 1631 & 15 \\
\hline JS14-2-14 & 304 & 515 & 0.6 & 0.0959 & 0.0014 & 3.4670 & 0.0543 & 0.2610 & 0.0019 & 1546 & 28 & 1520 & 12 & 1495 & 10 \\
\hline JS14-2-15 & 45 & 81 & 0.6 & 0.1029 & 0.0021 & 4.1844 & 0.0934 & 0.2940 & 0.0032 & 1676 & 38 & 1671 & 18 & 1662 & 16 \\
\hline JS14-2-16 & 57 & 93 & 0.6 & 0.1089 & 0.0022 & 4.3012 & 0.0941 & 0.2851 & 0.0029 & 1783 & 36 & 1694 & 18 & 1617 & 15 \\
\hline JS14-2-17 & 98 & 108 & 0.9 & 0.0971 & 0.0019 & 3.8585 & 0.0786 & 0.2874 & 0.0029 & 1570 & 36 & 1605 & 16 & 1629 & 15 \\
\hline JS14-2-18 & 574 & 313 & 1.8 & 0.1187 & 0.0018 & 4.8443 & 0.0790 & 0.2946 & 0.0027 & 1937 & 28 & 1793 & 14 & 1665 & 13 \\
\hline JS14-2-19 & 247 & 322 & 0.8 & 0.1319 & 0.0020 & 7.1390 & 0.1182 & 0.3905 & 0.0036 & 2124 & 26 & 2129 & 15 & 2125 & 17 \\
\hline JS14-2-20 & 247 & 171 & 1.4 & 0.0987 & 0.0017 & 3.8598 & 0.0685 & 0.2821 & 0.0026 & 1600 & 31 & 1605 & 14 & 1602 & 13 \\
\hline JS14-2-21 & 172 & 193 & 0.9 & 0.1394 & 0.0020 & 7.9578 & 0.1202 & 0.4120 & 0.0036 & 2220 & 25 & 2226 & 14 & 2224 & 17 \\
\hline JS14-2-23 & 33 & 83 & 0.4 & 0.1810 & 0.0029 & 13.2559 & 0.2338 & 0.5279 & 0.0056 & 2662 & 27 & 2698 & 17 & 2733 & 24 \\
\hline JS14-2-24 & 69 & 146 & 0.5 & 0.1870 & 0.0031 & 13.6770 & 0.2431 & 0.5269 & 0.0054 & 2716 & 27 & 2728 & 17 & 2728 & 23 \\
\hline JS14-2-25 & 183 & 369 & 0.5 & 0.0979 & 0.0016 & 3.8415 & 0.0663 & 0.2829 & 0.0029 & 1584 & 30 & 1601 & 14 & 1606 & 15 \\
\hline JS14-2-26 & 102 & 148 & 0.7 & 0.0972 & 0.0018 & 3.7338 & 0.0680 & 0.2775 & 0.0026 & 1572 & 34 & 1579 & 15 & 1579 & 13 \\
\hline JS14-2-27 & 146 & 221 & 0.7 & 0.1942 & 0.0027 & 14.6311 & 0.2145 & 0.5425 & 0.0048 & 2789 & 56 & 2792 & 14 & 2794 & 20 \\
\hline JS14-2-28 & 135 & 209 & 0.6 & 0.1768 & 0.0026 & 11.9383 & 0.1747 & 0.4868 & 0.0040 & 2623 & 24 & 2600 & 14 & 2557 & 17 \\
\hline JS14-2-29 & 20 & 44 & 0.4 & 0.0991 & 0.0028 & 3.9989 & 0.1182 & 0.2931 & 0.0043 & 1609 & 54 & 1634 & 24 & 1657 & 21 \\
\hline JS14-2-30 & 1182 & 553 & 2.1 & 0.1224 & 0.0021 & 4.4443 & 0.1004 & 0.2614 & 0.0043 & 1992 & 36 & 1721 & 19 & 1497 & 22 \\
\hline
\end{tabular}

Note: Concordance $($ conc. $)=\left({ }^{206} \mathrm{~Pb} /{ }^{238} \mathrm{U}\right.$ age $) /\left({ }^{207} \mathrm{~Pb} /{ }^{235} \mathrm{U}\right.$ age $) \times 100 \%$. 
Table A5. LA-ICP-MS zircon Hf isotope analyses for sample JS14-1 from the Dagushi Gp.

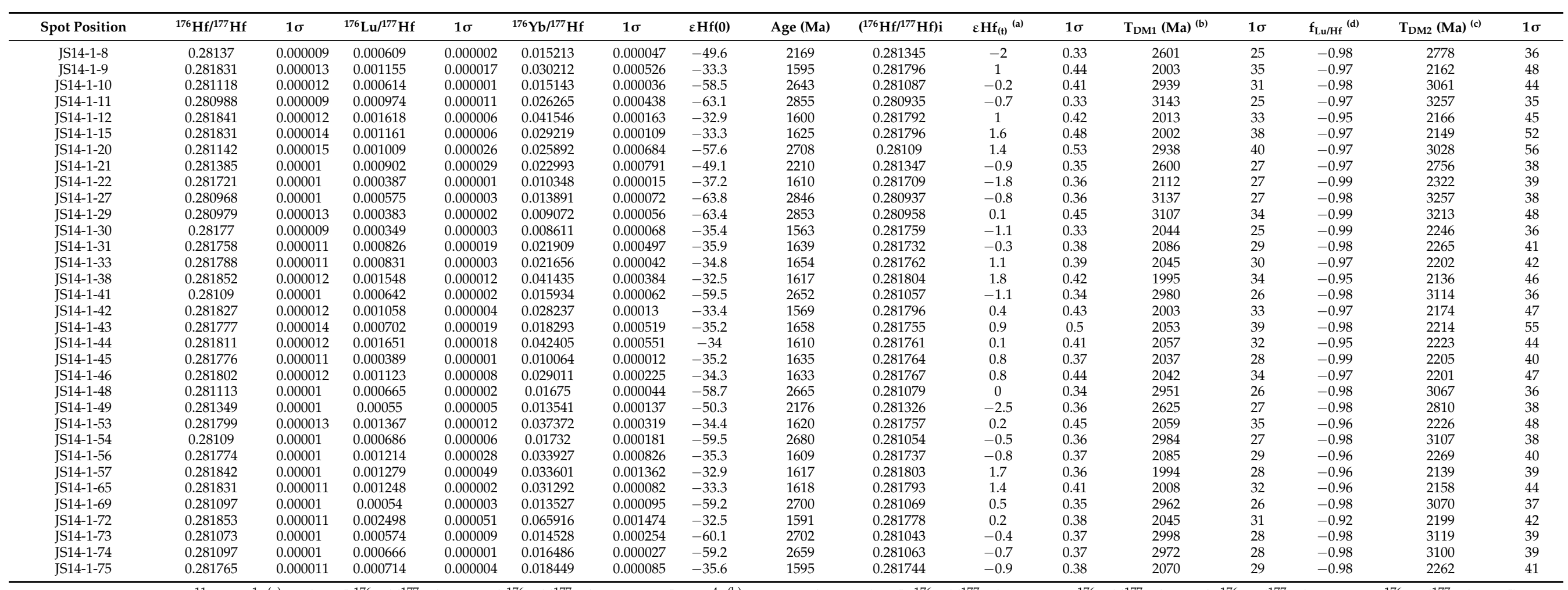

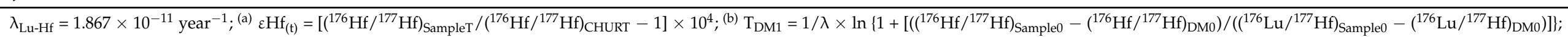

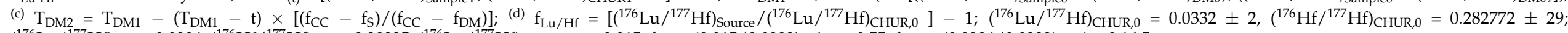

$\left({ }^{16} \mathrm{Lu} /{ }^{177} \mathrm{Hf}\right)_{\mathrm{DM}}=0.0384,\left({ }^{176} \mathrm{Hf} /{ }^{177} \mathrm{Hf}\right)_{\mathrm{DM}}=0.28325,\left({ }^{176} \mathrm{Lu} /{ }^{177} \mathrm{Hf}\right)_{\text {mean }}$ crust $=0.015, \mathrm{f}_{\mathrm{CC}}=(0.015 / 0.0332)-1=-0.55, \mathrm{f}_{\mathrm{DM}}=(0.0384 / 0.0332)-1=0.16 .5$. 
Table A6. Trace element analyses of the 1.60 Ga detrital zircons for samples JS14-1 and JS14-2 from the Dagushi Gp (ppm).

\begin{tabular}{|c|c|c|c|c|c|c|c|c|c|c|c|c|c|c|c|c|c|c|c|}
\hline Spot No. & $\mathbf{T i}$ & $\mathbf{Y}$ & $\mathrm{Nb}$ & $\mathrm{Ce}$ & $\mathrm{Nd}$ & $\mathrm{Sm}$ & Eu & Gd & $\mathbf{T b}$ & Dy & Ho & Er & Tm & $\mathbf{Y b}$ & Lu & Hf & Ta & Th & $\mathbf{U}$ \\
\hline JS14-1-2 & 14 & 1128 & 3 & 7 & 11 & 15 & 7 & 57 & 15 & 140 & 43 & 156 & 28 & 246 & 43 & 6143 & 1 & 36 & 57 \\
\hline JS14-1-3 & 8 & 1247 & 13 & 23 & 6 & 9 & 2 & 42 & 13 & 140 & 47 & 186 & 36 & 313 & 56 & 6592 & 4 & 111 & 145 \\
\hline JS14-1-4 & 12 & 683 & 6 & 18 & 2 & 3 & 0 & 18 & 6 & 65 & 24 & 102 & 21 & 200 & 37 & 9331 & 3 & 147 & 253 \\
\hline JS14-1-9 & 10 & 1561 & 20 & 60 & 7 & 12 & 5 & 53 & 16 & 169 & 57 & 230 & 44 & 386 & 68 & 6663 & 5 & 90 & 117 \\
\hline JS14-1-12 & 6 & 2463 & 36 & 88 & 9 & 13 & 5 & 66 & 22 & 253 & 89 & 369 & 72 & 636 & 111 & 7287 & 7 & 146 & 198 \\
\hline JS14-1-14 & 13 & 1064 & 6 & 1137 & 743 & 142 & 13 & 134 & 21 & 153 & 42 & 142 & 25 & 216 & 37 & 8190 & 3 & 56 & 90 \\
\hline JS14-1-15 & 6 & 1027 & 28 & 90 & 3 & 5 & 2 & 25 & 9 & 103 & 38 & 157 & 31 & 275 & 48 & 6393 & 6 & 58 & 94 \\
\hline JS14-1-18 & 8 & 784 & 12 & 25 & 2 & 3 & 0 & 17 & 6 & 71 & 27 & 123 & 26 & 257 & 49 & 10,565 & 5 & 120 & 219 \\
\hline JS14-1-19 & 8 & 2531 & 13 & 29 & 14 & 23 & 4 & 95 & 27 & 289 & 96 & 371 & 69 & 590 & 100 & 6801 & 4 & 138 & 169 \\
\hline JS14-1-22 & 24 & 561 & 5 & 9 & 3 & 6 & 1 & 21 & 7 & 67 & 22 & 84 & 16 & 143 & 24 & 8226 & 3 & 36 & 60 \\
\hline JS14-1-24 & 10 & 1922 & 13 & 76 & 7 & 12 & 3 & 53 & 19 & 207 & 72 & 295 & 58 & 522 & 91 & 7791 & 4 & 105 & 88 \\
\hline JS14-1-25 & 10 & 1169 & 29 & 103 & 4 & 7 & 3 & 34 & 11 & 122 & 43 & 173 & 33 & 294 & 50 & 6596 & 7 & 158 & 152 \\
\hline JS14-1-26 & 18 & 815 & 17 & 73 & 2 & 3 & 1 & 14 & 6 & 68 & 28 & 129 & 28 & 264 & 49 & 6893 & 4 & 46 & 65 \\
\hline JS14-1-28 & 8 & 1222 & 18 & 121 & 19 & 9 & 2 & 28 & 10 & 113 & 43 & 190 & 40 & 362 & 66 & 7072 & 5 & 66 & 76 \\
\hline JS14-1-30 & 19 & 466 & 3 & 19 & 1 & 3 & 0 & 11 & 4 & 43 & 16 & 69 & 15 & 143 & 26 & 9801 & 2 & 112 & 166 \\
\hline JS14-1-31 & 13 & 643 & 7 & 10 & 4 & 6 & 3 & 26 & 7 & 75 & 24 & 94 & 17 & 151 & 27 & 7997 & 2 & 29 & 64 \\
\hline JS14-1-33 & 18 & 1096 & 2 & 7 & 11 & 14 & 7 & 54 & 14 & 135 & 43 & 154 & 28 & 241 & 43 & 7068 & 1 & 34 & 55 \\
\hline JS14-1-34 & 11 & 1723 & 44 & 737 & 268 & 59 & 14 & 93 & 21 & 196 & 64 & 249 & 47 & 396 & 67 & 6893 & 9 & 244 & 214 \\
\hline JS14-1-38 & 11 & 1123 & 24 & 70 & 4 & 7 & 3 & 31 & 10 & 115 & 41 & 168 & 34 & 306 & 55 & 7682 & 7 & 82 & 130 \\
\hline JS14-1-42 & 9 & 1234 & 36 & 114 & 3 & 6 & 3 & 31 & 11 & 121 & 45 & 187 & 37 & 325 & 57 & 6958 & 8 & 180 & 201 \\
\hline JS14-1-43 & 12 & 1039 & 3 & 7 & 9 & 14 & 6 & 52 & 13 & 129 & 40 & 147 & 27 & 234 & 41 & 7519 & 1 & 34 & 55 \\
\hline JS14-1-45 & 6 & 584 & 11 & 18 & 3 & 4 & 1 & 19 & 6 & 64 & 22 & 87 & 17 & 150 & 26 & 9042 & 4 & 41 & 99 \\
\hline JS14-1-46 & 6 & 748 & 9 & 23 & 4 & 6 & 1 & 25 & 8 & 82 & 28 & 113 & 22 & 198 & 36 & 6546 & 3 & 46 & 81 \\
\hline JS14-1-47 & 16 & 1592 & 7 & 10 & 11 & 17 & 7 & 73 & 20 & 194 & 62 & 232 & 42 & 364 & 64 & 7591 & 3 & 73 & 120 \\
\hline JS14-1-50 & 7 & 1001 & 15 & 47 & 10 & 6 & 1 & 23 & 8 & 92 & 36 & 159 & 34 & 326 & 62 & 12,092 & 6 & 166 & 295 \\
\hline JS14-1-53 & 6 & 1003 & 17 & 25 & 3 & 7 & 2 & 37 & 12 & 117 & 39 & 152 & 29 & 258 & 45 & 7625 & 5 & 111 & 144 \\
\hline
\end{tabular}


Table A6. Cont.

\begin{tabular}{|c|c|c|c|c|c|c|c|c|c|c|c|c|c|c|c|c|c|c|c|}
\hline Spot No. & $\mathrm{Ti}$ & $Y$ & $\mathrm{Nb}$ & $\mathrm{Ce}$ & $\mathrm{Nd}$ & $\mathrm{Sm}$ & $\mathbf{E u}$ & $\mathrm{Gd}$ & $\mathrm{Tb}$ & Dy & Нo & Er & $\operatorname{Tm}$ & $\mathrm{Yb}$ & $\mathbf{L u}$ & Hf & $\mathrm{Ta}$ & Th & $\mathbf{U}$ \\
\hline JS14-1-56 & 4 & 2084 & 26 & 895 & 508 & 114 & 2 & 147 & 31 & 267 & 82 & 308 & 57 & 478 & 79 & 9597 & 9 & 308 & 532 \\
\hline JS14-1-57 & 12 & 1359 & 35 & 117 & 5 & 8 & 3 & 35 & 12 & 138 & 50 & 207 & 41 & 362 & 63 & 8013 & 8 & 189 & 207 \\
\hline JS14-1-58 & 51 & 4816 & 16 & 48 & 54 & 122 & 50 & 437 & 102 & 756 & 187 & 612 & 105 & 851 & 139 & 7149 & 3 & 1029 & 439 \\
\hline JS14-1-63 & 21 & 2005 & 18 & 70 & 9 & 14 & 5 & 59 & 21 & 227 & 80 & 319 & 64 & 512 & 88 & 7342 & 6 & 113 & 136 \\
\hline JS14-1-65 & 11 & 1274 & 30 & 134 & 3 & 6 & 2 & 28 & 10 & 121 & 47 & 208 & 47 & 420 & 79 & 7800 & 7 & 196 & 174 \\
\hline JS14-1-66 & 21 & 1072 & 3 & 9 & 6 & 8 & 3 & 40 & 12 & 124 & 43 & 169 & 35 & 287 & 53 & 8654 & 1 & 47 & 72 \\
\hline JS14-1-68 & 6 & 1362 & 38 & 199 & 35 & 13 & 4 & 41 & 13 & 145 & 54 & 215 & 44 & 359 & 64 & 7444 & 9 & 158 & 176 \\
\hline JS14-1-72 & 12 & 2125 & 50 & 228 & 4 & 9 & 4 & 49 & 17 & 204 & 79 & 339 & 73 & 629 & 118 & 7241 & 12 & 479 & 315 \\
\hline JS14-1-75 & 6 & 691 & 9 & 26 & 3 & 6 & 1 & 27 & 8 & 82 & 29 & 110 & 22 & 189 & 35 & 7209 & 3 & 46 & 78 \\
\hline JS14-2-2 & 10 & 522 & 7 & 9 & 8 & 9 & 6 & 30 & 8 & 77 & 23 & 83 & 16 & 127 & 21 & 5349 & 3 & 146 & 67 \\
\hline JS14-2-4 & 7 & 1001 & 20 & 88 & 2 & 4 & 1 & 20 & 7 & 87 & 35 & 163 & 36 & 327 & 62 & 7996 & 5 & 91 & 100 \\
\hline JS14-2-5 & 8 & 993 & 8 & 16 & 4 & 7 & 1 & 36 & 11 & 116 & 39 & 152 & 29 & 236 & 42 & 9450 & 3 & 99 & 154 \\
\hline JS14-2-9 & 11 & 1540 & 5 & 11 & 10 & 17 & 8 & 97 & 29 & 229 & 62 & 207 & 38 & 298 & 51 & 8566 & 2 & 53 & 89 \\
\hline JS14-2-12 & 8 & 1169 & 25 & 95 & 2 & 4 & 2 & 22 & 8 & 102 & 42 & 188 & 43 & 385 & 73 & 7475 & 6 & 88 & 106 \\
\hline JS14-2-13 & 27 & 831 & 3 & 17 & 5 & 7 & 1 & 30 & 8 & 89 & 30 & 121 & 26 & 220 & 40 & 9480 & 1 & 127 & 136 \\
\hline JS14-2-14 & 6 & 3069 & 14 & 17 & 12 & 24 & 3 & 113 & 34 & 349 & 119 & 455 & 87 & 673 & 112 & 10,350 & 5 & 346 & 552 \\
\hline JS14-2-17 & 7 & 1004 & 20 & 94 & 2 & 4 & 1 & 21 & 7 & 87 & 36 & 161 & 36 & 328 & 62 & 8113 & 5 & 108 & 112 \\
\hline JS14-2-20 & 11 & 1763 & 33 & 259 & 44 & 15 & 4 & 47 & 15 & 171 & 64 & 274 & 58 & 506 & 91 & 6912 & 7 & 268 & 176 \\
\hline JS14-2-25 & 5 & 1145 & 19 & 16 & 3 & 7 & 0 & 33 & 11 & 124 & 44 & 179 & 36 & 298 & 50 & 10,250 & 6 & 206 & 396 \\
\hline JS14-2-26 & 12 & 2365 & 10 & 18 & 22 & 32 & 12 & 130 & 34 & 315 & 97 & 341 & 63 & 497 & 85 & 8189 & 4 & 119 & 161 \\
\hline JS14-2-29 & 27 & 394 & 6 & 18 & 7 & 3 & 1 & 14 & 4 & 46 & 15 & 59 & 13 & 108 & 19 & 8614 & 2 & 22 & 48 \\
\hline
\end{tabular}




\section{References}

1. Rogers, J.J.W.; Santosh, M. Configuration of Columbia, a Mesoproterozoic Supercontinent. Gondwana Res. 2002, 5, 5-22. [CrossRef]

2. Zhao, G.; Cawood, P.A.; Wilde, S.A.; Sun, M. Review of global 2.1-1.8 Ga orogens: Implications for a pre-Rodinia supercontinent. Earth Sci. Rev. 2002, 59, 125-162. [CrossRef]

3. Evans, D.A.D.; Mitchell, R.N. Assembly and breakup of the core of Paleoproterozoic-Mesoproterozoic supercontinent Nuna. Geology 2011, 39, 443-446. [CrossRef]

4. Zhao, G.C.; Cawood, P.A. Precambrian geology of China. Precambrian Res. 2012, 222, 13-54. [CrossRef]

5. Meert, J.G.; Santosh, M. The Columbia supercontinent revisited. Gondwana Res. 2017, 50, 67-83. [CrossRef]

6. Zhao, G.C.; Sun, M.; Wilde, S.A.; Li, S.Z. A Paleo-Mesoproterozoic supercontinent: Assembly, growth and breakup. Earth Sci. Rev. 2004, 67, 91-123. [CrossRef]

7. Pisarevsky, S.A.; Elming, S.Å.; Pesonen, L.J.; Li, Z.X. Mesoproterozoic paleogeography: Supercontinent and beyond. Precambrian Res. 2014, 244, 207-225. [CrossRef]

8. Fan, H.P.; Zhu, W.G.; Li, Z.X.; Zhong, H.; Bai, Z.J.; He, D.F.; Chen, C.J.; Cao, C.Y. Ca. 1.5 Ga mafic magmatism in South China during the break-up of the supercontinent Nuna/Columbia: The Zhuqing Fe-Ti-V oxide ore-bearing mafic intrusions in western Yangtze Block. Lithos 2013, 168-169, 85-98. [CrossRef]

9. Condie, K.C.; Belousova, E.; Griffin, W.L.; Sircombe, K.N. Granitoid events in space and time: Constraints from igneous and detrital zircon age spectra. Gondwana Res. 2009, 15, 228-242. [CrossRef]

10. Guan, J.L.; Zheng, L.L.; Liu, J.H.; Sun, Z.M.; Cheng, W.H. Zircons SHRIMP U-Pb Dating of Diabase from Hekou, Sichuan Province, China and Its Geological Significance. Acta Geol. Sin. 2011, 85, 482-490.

11. Chen, W.T.; Zhou, M.F.; Zhao, X.F. Late Paleoproterozoic sedimentary and mafic rocks in the Hekou area, SW China: Implication for the reconstruction of the Yangtze Block in Columbia. Precambrian Res. 2013, 231, 61-77. [CrossRef]

12. Hou, L.; Ding, J.; Deng, J.; Peng, H.J. Geology, geochronology, and geochemistry of the Yinachang Fe-Cu-Au-REE deposit of the Kangdian region of SW China: Evidence for a Paleo-Mesoproterozoic tectono-magmatic event and associated IOCG systems in the western Yangtze Block. J. Asian Earth Sci. 2015, 103, 129-149. [CrossRef]

13. Greentree, M.R.; Li, Z.X. The oldest known rocks in south-western China: SHRIMP U-Pb magmatic crystallisation age and detrital provenance analysis of the Paleoproterozoic Dahongshan Group. J. Asian Earth Sci. 2008, 33, 289-302. [CrossRef]

14. Zhao, X.F.; Zhou, M.F.; Li, J.W.; Sun, M.; Gao, J.F.; Sun, W.H.; Yang, J.H. Late Paleoproterozoic to early Mesoproterozoic Dongchuan Group in Yunnan, SW China: Implications for tectonic evolution of the Yangtze Block. Precambrian Res. 2010, 182, 57-69. [CrossRef]

15. Wang, W.; Zhou, M.F. Provenance and tectonic setting of the Paleo-to Mesoproterozoic Dongchuan Group in the southwestern Yangtze Block, South China: Implication for the breakup of the supercontinent Columbia. Tectonophysics 2014, 610, 110-127. [CrossRef]

16. Wang, W.; Zhou, M.F.; Zhao, X.F.; Chen, W.T.; Yan, D.P. Late Paleoproterozoic to Mesoproterozoic rift successions in SW China: Implication for the Yangtze Block-North Australia-Northwest Laurentia connection in the Columbia supercontinent. Sediment. Geol. 2014, 309, 33-47. [CrossRef]

17. Xiong, X.W.; Chen, Y.Y. Sedimentary features and its significance of tectono-paleogeography of Dagushi Group, Jingshan, Hubei province. Earth Sci. J. China Univ. Geosci. 1991, 16, 489-495. (In Chinese)

18. Xiao, Z.B. Research of the Detrital Zircon from Mesoproterozoic Sedimentary Strata in the North Margin of Yangtze Craton, China. Master's Thesis, Northwest University, Xi'an, China, 2012.

19. Li, H.K.; Tian, H.; Zhou, H.Y.; Zhang, J.; Liu, H.; Geng, J.Z.; Ye, L.J.; Xiang, Z.Q.; Qu, Y.S. Correlation between the Dagushi Group in the Dahongshan Area and the Shennongjia Group in the Shennongjia Area on the northern margin of the Yangtze Craton: Constraints from zircon U-Pb ages and Lu-Hf isotopic systematics. Earth Sci. Front. 2016, 23, 186-201.

20. Yang, Z.N. The Paleoproterozoic to Middle Neoproterozoic Tectonic Evolution of the Suizhou-Yingshan Terrain and Its Surrounding Area in the Northern Yangtze Block. Ph.D. Thesis, Chinese University of Geosciences, Wuhan, China, 2018.

21. Li, H.K.; Zhang, C.L.; Xiang, Z.Q.; Lu, S.N.; Zhang, J.; Geng, J.Z.; Qu, L.S.; Wang, Z.X. Zircon and baddeleyite U-Pb geochronology of the Shennongjia Group in the Yangtze Craton and its tectonic significance. Acta Petrol. Sin. 2013, $29,673-697$.

22. Du, Q.D.; Wang, Z.J.; Wang, J.; Deng, Q.; Yang, F. Geochronology and geochemistry of tuff beds from the Shicaohe Formation of Shennongjia Group and tectonic evolution in the northern Yangtze Block, South China. Int. J. Earth Sci. 2016, 105, 521-535. [CrossRef]

23. Qiu, X.F.; Yang, H.M.; Lu, S.S.; Ling, W.L.; Zhang, L.G.; Tan, J.J.; Wang, Z.X. Geochronology and geochemistry of Grenville-aged $(1063 \pm 16 \mathrm{Ma})$ metabasalts in the Shennongjia district, Yangtze block: Implications for tectonic evolution of the South China Craton. Int. Geol. Rev. 2015, 57, 76-96. [CrossRef]

24. Wang, L.J.; Griffin, W.L.; Yu, J.H.; O'Reilly, S.Y. U-Pb and Lu-Hf isotopes in detrital zircon from Neoproterozoic sedimentary rocks in the northern Yangtze Block: Implications for Precambrian crustal evolution. Gondwana Res. 2013, 23, 1261-1272. [CrossRef]

25. Wu, Y.B.; Gao, S.; Gong, H.J.; Xiang, H.; Jiao, W.F.; Yang, S.H.; Liu, Y.S.; Yuan, H.L. Zircon U-Pb age, trace element and Hf isotope composition of Kongling terrane in the Yangtze Craton: Refining the timing of Palaeoproterozoic high-grade metamorphism. J. Metamorph. Geol. 2009, 27, 461-477. [CrossRef] 
26. Yang, Z.N.; Yang, K.G.; Polat, A.; Xu, Y. Early crustal evolution of the eastern Yangtze Block: Evidence from detrital zircon $\mathrm{U}-\mathrm{Pb}$ ages and $\mathrm{Hf}$ isotopic composition of the Neoproterozoic Huashan Group in the Dahongshan Area. Precambrian Res. 2018, 309, 248-270. [CrossRef]

27. Du, Q.D.; Wang, Z.J.; Wang, J.; Qiu, Y.S.; Jiang, X.S.; Deng, Q.; Yang, F. Geochronology and paleoenvironment of the pre-Sturtian glacial strata: Evidence from the Liantuo Formation in the Nanhua rift basin of the Yangtze Block, South China. Precambrian Res. 2013, 233, 118-131. [CrossRef]

28. Hu, Z.X.; Liu, C.; Mao, X.W.; Deng, Q.Z.; Yang, J.X.; Li, L.J.; Kong, L.Y. Documentation of Jingningian island-arc volcanic rocks and accretionary complexes in the Dahongshan Region, northern Hubei and its tectonic significance. Resour. Environ. Eng. 2015, $29,757-766$.

29. BGMRHB. Regional Geological Survey Report (Kedianpo, Guchengfan and Sanyangdian Areas, 1:50,000); BGMRHB: Hubei, China, 1986. (In Chinese)

30. Liu, H.; Xu, D.L.; Wei, Y.X.; Deng, X.; Peng, L.H. Depositional age of the Dagushi Group in the Dahong Mountain, Hubei Province: Evidence from U-Pb ages of detrital zircons. Geol. Bull. China 2017, 36, 715-725.

31. Wiedenbeck, M.; Allé, P.; Corfu, F.; Griffin, W.L.; Meier, M.; Oberli, F.; Quadt, A.V.; Roddick, J.C.; Spiegel, W. Three natural zircon standards for U-Th-Pb, Lu-Hf, trace element and REE analyses. Geostand. Newslet. 1995, 19, 1-23. [CrossRef]

32. Jackson, S.E.; Pearson, N.J.; Griffin, W.L.; Belousova, E.A. The application of laser ablation-inductively coupled plasma-mass spectrometry to in situ U-Pb zircon geochronology. Chem. Geol. 2004, 211, 47-69. [CrossRef]

33. Liu, Y.S.; Hu, Z.C.; Gao, S.; Günther, D.; Xu, J.; Gao, C.G.; Chen, H.H. In situ analysis of major and trace elements of anhydrous minerals by LA-ICP-MS without applying an internal standard. Chem. Geol. 2008, 257, 34-43. [CrossRef]

34. Ludwig, K.R. User's Manual for Isoplot 3.00: A Geochronological Toolkit for Excel; Berkeley Geochronology Center Special Publication: Berkeley, CA, USA, 2003; Volume 4, 67p.

35. Black, L.P.; Kamo, S.L.; Allen, C.M.; Aleinikoff, J.N.; Davis, D.W.; Korsch, R.J.; Foudoulis, C. TEMORA 1: A new zircon standard for U-Pb geochronology. Chem. Geol. 2003, 200, 155-170. [CrossRef]

36. He, Z.Y.; Klemd, R.; Zhang, Z.M.; Zong, K.Q.; Sun, L.X.; Tian, Z.L.; Huang, B.T. Mesoproterozoic continental arc magmatism and crustal growth in the eastern Central Tianshan Arc Terrane of the southern Central Asian Orogenic Belt: Geochronological and geochemical evidence. Lithos 2015, 236-237, 74-89. [CrossRef]

37. Jochum, K.P.; Weis, U.; Stoll, B.; Kuzmin, D.; Yang, Q.; Raczek, I.; Jacob, D.E.; Stracke, A.; Birbaum, K.; Frick, D.A.; et al. Determination of reference values for NIST SRM 610-617 glasses following ISO guidelines. Geostand. Geoanal. Res. 2011, 35, 397-429. [CrossRef]

38. Yuan, H.L.; Gao, S.; Liu, X.M.; Li, H.M.; Günther, D.; Wu, F.Y. Accurate U-Pb Age and Trace Element Determinations of Zircon by Laser Ablation-Inductively Coupled Plasma-Mass Spectrometry. Geostand. Geoanal. Res. 2004, 11, 353-370. [CrossRef]

39. Hu, Z.C.; Liu, Y.S.; Gao, S.; Liu, W.G.; Zhang, W.; Tong, X.R.; Lin, L.; Zong, K.Q.; Li, M.; Chen, H.H. Improved in situ Hf isotope ratio analysis of zircon using newly designed $\mathrm{X}$ skimmer cone and jet sample cone in combination with the addition of nitrogen by laser ablation multiple collector ICP-MS. J. Anal. At. Spectrom. 2012, 27, 1391-1399. [CrossRef]

40. Liu, Y.S.; Gao, S.; Hu, Z.C.; Gao, C.G.; Zong, K.Q.; Wang, D.B. Continental and Oceanic Crust Recycling-induced Melt-peridotite Interactions in the Trans-north China Orogen: U-Pb dating, Hf isotopes and trace elements in Zircons from Mantle Xenoliths. J. Pet. Sci. Eng. 2010, 51, 537-571. [CrossRef]

41. Patchett, J.; Kouvo, O. Origin of continental crust of 1.9-1.7 Ga age: Nd isotopes and U-Pb zircon ages in the Svecokarelian terrain of South Finland. Contrib. Min. Pet. 1986, 92, 1-12. [CrossRef]

42. Segal, I.; Halica, L.; Platzner, I.T. Accurate isotope ratio measurements of ytterbium by multiple collection inductively coupled plasma mass spectrometry applying erbium and hafnium in an improved double external normalization procedure. J. Anal. At. Spectrom. 2003, 18, 1217-1223. [CrossRef]

43. Fisher, C.M.; Vervoort, J.D.; Hanchar, J.M. Guidelines for reporting zircon Hf isotopic data by LA-MC-ICPMS and potential pitfalls in the interpretation of these data. Chem. Geol. 2014, 363, 125-133. [CrossRef]

44. Blichert-Toft, J.; Albarède, F. The Lu-Hf isotope geochemistry of chondrites and the evolution of the mantle-crust system. Earth Planet. Sci. Lett. 1997, 148, 243-258. [CrossRef]

45. Blichert-Toft, J. The Hf isotopic composition of zircon reference material 91500. Chem. Geol. 2008, 253, 252-257. [CrossRef]

46. Söderlund, U.; Patchett, P.J.; Vervoort, J.D.; Isachsen, C.E. The 176Lu decay constant determined by Lu-Hf and U-Pb isotope systematics of Precambrian mafic intrusions. Earth Planet. Sci. Lett. 2004, 219, 311-324. [CrossRef]

47. Griffin, W.L.; Pearson, N.J.; Belousova, E.; Jackson, S.E.; Van Achterbergh, E.; O’Reilly, S.Y.; Shee, S.R. The Hf isotope composition of cratonic mantle: LAM-MC-ICPMS analysis of zircon megacrysts in kimberlites. Geochim. Cosmochim. Acta 2000, 64, 133-147. [CrossRef]

48. Griffin, W.L.; Wang, X.; Jackson, S.E.; Pearson, N.J.; O’Reilly, S.Y.; Xu, X.; Zhou, X. Zircon chemistry and magma mixing, SE China: In-situ analysis of Hf isotopes, Tonglu and Pingtan igneous complexes. Lithos 2002, 61, 237-269. [CrossRef]

49. Kong, L.Y.; Mao, X.W.; Chen, C.; Deng, Q.Z.; Zhang, H.J.; Yang, Q.X.; Li, L.J.; Li, Q.W. Chronological study on detrital zircons and its geological significance from Mesoproterozoic Dagushi Group in the Dahongshan Area, north margin of the Yangtze Block. Earth Sci. 2017, 42, 485-501.

50. Chen, K.; Gao, S.; Wu, Y.B.; Guo, J.L.; Hu, Z.C.; Liu, Y.S.; Zong, K.Q.; Liang, Z.W.; Geng, X.L. 2.6-2.7 Ga crustal growth in Yangtze craton, South China. Precambrian Res. 2013, 224, 472-490. [CrossRef] 
51. Guo, J.L.; Wu, Y.B.; Gao, S.; Jin, Z.M.; Zong, K.Q.; Hu, Z.C.; Chen, K.; Chen, H.H.; Liu, Y.S. Episodic Paleoarche-anPaleoproterozoic (3.3-2.0 Ga) granitoid magmatism in Yangtze Craton, South China: Implications for late Archean tec-tonics. Precambrian Res. 2015, 270, 246-266. [CrossRef]

52. Wang, Z.J.; Wang, J.; Du, Q.D.; Deng, Q.; Yang, F. The evolution of the Central Yangtze Block during early Neoarchean time: Evidence from geochronology and geochemistry. J. Asian Earth Sci. 2013, 77, 31-44. [CrossRef]

53. Zhou, G.Y.; Wu, Y.B.; Gao, S.; Yang, J.Z.; Zheng, J.P.; Qin, Z.W.; Wang, H.; Yang, S.H. The 2.65 Ga A-type granite in the northeastern Yangtze craton: Petrogenesis and geological implications. Precambrian Res. 2015, 258, 247-259. [CrossRef]

54. Qiu, Y.M.; Gao, S.; McNaughton, N.J.; Groves, D.I.; Ling, W.L. First evidence of $>3.2$ Ga continental crust in the Yangtze craton of south China and its implications for Archean crustal evolution and Phanerozoic tectonics. Geology 2000, 28, 11-14. [CrossRef]

55. Zhang, S.B.; Zheng, Y.F.; Wu, Y.B.; Zhao, Z.F.; Gao, S.; Wu, F.Y. Zircon isotope evidence for $\geq 3.5$ Ga continental crust in the Yangtze craton of China. Precambrian Res. 2006, 146, 16-34. [CrossRef]

56. Jiao, W.F.; Wu, Y.B.; Yang, S.H.; Peng, M.; Wang, J. The oldest basement rock in the Yangtze Craton revealed by zircon U-Pb age and Hf isotope composition. Sci. China Ser. D Earth Sci. 2009, 52, 1393-1399. [CrossRef]

57. Gao, S.; Yang, J.; Zhou, L.; Li, M.; Hu, Z.C.; Guo, J.L.; Yuan, H.L.; Gong, H.J.; Xiao, G.Q.; Wei, J.Q. Age and growth of the Archean Kongling terrain, South China, with emphasis on 3.3 ga granitoid gneisses. Am. J. Sci. 2011, 311, 153-182. [CrossRef]

58. Guo, J.L.; Gao, S.; Wu, Y.B.; Li, M.; Chen, K.; Hu, Z.C.; Liang, Z.W.; Liu, Y.S.; Zhou, L.; Zong, K.Q. 3.45 Ga granitic gneisses from the Yangtze Craton, South China: Implications for Early Archean crustal growth. Precambrian Res. 2014, 242, 82-95. [CrossRef]

59. Zhang, S.B.; Zheng, Y.F.; Wu, Y.B.; Zhao, Z.F.; Gao, S.; Wu, F.Y. Zircon U-Pb age and Hf-O isotope evidence for Paleoproterozoic metamorphic event in South China. Precambrian Res. 2006, 151, 265-288. [CrossRef]

60. Xiong, Q.; Zheng, J.P.; Yu, C.M.; Su, Y.P.; Tang, H.Y.; Zhang, Z.H. Zircon U-Pb age and Hf isotope of Quanyishang A-type granite in Yichang: Signification for the Yangtze continental cratonization in Paleoproterozoic. Chin. Sci. Bull. 2009, 54, 436-446. [CrossRef]

61. Wang, Z.J.; Wang, J.; Deng, Q.; Du, Q.D.; Zhou, X.L.; Yang, F.; Liu, H. Paleoproterozoic I-type granites and their im-plications for the Yangtze block position in the Columbia supercontinent: Evidence from the Lengshui Complex, South China. Precambrian Res. 2015, 263, 157-173. [CrossRef]

62. Han, Q.S.; Peng, S.B.; Kusky, T.; Polat, A.; Jiang, X.F.; Cen, Y.; Liu, S.F.; Deng, H. A Paleoproterozoic ophiolitic mélange, Yangtze craton, South China: Evidence for Paleoproterozoic suturing and microcontinent amalgamation. Precambrian Res. 2017, 293, 13-38. [CrossRef]

63. Zhou, G.Y.; Wu, Y.B.; Wang, H.; Qin, Z.W.; Zhang, W.X.; Zheng, J.P.; Yang, S.H. Petrogenesis of the Huashanguan A-type granite complex and its implications for the early evolution of the Yangtze Block. Precambrian Res. 2017, 292, 57-74. [CrossRef]

64. Han, Q.S.; Peng, S.B.; Polat, A.; Kusky, T.; Deng, H.; Wu, T.Y. A ca.2.1 Ga Andean-type margin built on metasomatized lithosphere in the northern Yangtze craton, China: Evidence from high-Mg basalts and andesites. Precambrian Res. 2018, 309, 309-324. [CrossRef]

65. Zheng, Y.F.; Zhao, Z.F.; Wu, Y.B.; Zhang, S.B.; Liu, X.M.; Wu, F.Y. Zircon U-Pb age, Hf and O isotope constraints on protolith origin of ultrahigh-pressure eclogite and gneiss in the Dabie orogen. Chem. Geol. 2006, 231, 135-158. [CrossRef]

66. Li, Y.H.; Zheng, J.P.; Xiong, Q.; Wang, W.; Ping, X.Q.; Li, X.Y.; Tang, H.Y. Petrogenesis and tectonic implications of Paleoproterozoic metapelitic rocks in the Archean Kongling Complex from the northern Yangtze Craton, South China. Precambrian Res. 2016, 276, 158-177. [CrossRef]

67. Geng, Y.S.; Liu, Y.Q.; Gao, L.Z.; Peng, N.; Jiang, X.J. Geochronology of the Mesoproterozoic Tong'an Formation in Southwestern Margin of Yangtze Craton: New Evidence from Zircon LA-ICP-MS U-Pb Ages. Acta Geol. Sin. 2012, 86, 1479-1490. (In Chinese with English abstract)

68. Li, H.K.; Zhang, C.L.; Yao, C.Y.; Xiang, Z.Q. U-Pb zircon age and Hf isotope compositions of Mesoproterozoic sedimentary strata on the western margin of the Yangtze massif. Sci. China Earth Sci. 2013, 56, 628-639. [CrossRef]

69. Pang, W.H.; Ren, G.M.; Sun, Z.M.; Yin, F.G. Division and correlation of Paleo-Mesoproterozoic strata on the western margin of Yangtze Block: Evidence from the U-Pb age of tuff zircon in the Tongan Formation. Geol. China 2015, 42, 921-936.

70. Cawood, P.A.; Wang, W.; Zhao, T.Y.; Xu, Y.J.; Mulder, J.A.; Pisarevsky, S.A.; Zhang, L.M.; Gan, C.S.; He, H.Y.; Liu, H.C.; et al Deconstructing South China and consequences for reconstructing Nuna and Rodinia. Earth Sci. Rev. 2020, 204, 1-24. [CrossRef]

71. Liu, L.; Pan, L.K.; Du, Y.C.; Gong, Z.Y.; Luo, F. Geochemical characteristics and geological significance of Shicaohe volcanic rocks of Shennongjia Group in western Hubei Province. Resour. Environ. Eng. 2015, 29, 370-376.

72. Wang, N.S. Sedimentary Facies of the Middle Part of Shennongjia Group—An Example from Shennongjia Section, Shennongjia Region; Chinese Academy of Geological Science: Beijing, China, 2016.

73. Lu, S.N.; Chen, Z.H.; Xiang, Z.Q.; Li, H.K.; Li, H.M. U-Pb ages of detrital zircons from the para-metamorphic rocks of the Qinling Group and their geological significance. Earth Sci. Front. 2006, 13, 303-310.

74. Li, X.H.; Chen, F.K.; Guo, J.H.; Li, Q.L.; Xie, L.W.; Siebel, W. South China provenance of the lower-grade Penglai Group north of the Sulu UHP orogenic belt, eastern China: Evidence from detrital zircon ages and Nd-Hf isotopic composition. Geochem. J. 2007, 41, 29-45. [CrossRef]

75. Yang, L.; Chen, F.K.; Yang, Y.Z.; Li, S.Q.; Zhu, X.Y. Zircon U-Pb ages of the Qinling Group in Danfeng area: Recording Mesoproterozoic and Neoproterozoic magmatism and Early Paleozoic metamorphism in the North Qinling terrain. Acta Petrol. Sin. 2010, 26, 1589-1603, (In Chinese with English abstract). 
76. Chu, H.; Lu, S.N.; Wang, H.C.; Xiang, Z.Q.; Liu, H. U-Pb age spectrum of detrital zircons from the Fuzikuang Formation, Penglai Group in Changdao, Shandong Province. Acta Petrol. Sin. 2011, 27, 1017-1028. (In Chinese with English abstract)

77. Diwu, C.; Sun, Y.; Zhang, H.; Wang, Q.; Guo, A.L.; Fan, L.G. Episodic tectonothermal events of the western North China Craton and North Qinling Orogenic Belt in central China: Constraints from detrital zircon U-Pb ages. J. Asian Earth Sci. 2012, 47, 107-122. [CrossRef]

78. Wang, W.; Zhou, M.F.; Yan, D.P.; Li, J.W. Depositional age, provenance, and tectonic setting of the Neoproterozoic Sibao Group, southeastern Yangtze Block, South China. Precambrian Res. 2012, 192-195, 107-124. [CrossRef]

79. Yang, C.; Li, X.H.; Wang, X.C.; Lan, Z.W. Mid-Neoproterozoic angular unconformity in the Yangtze Block revisited: Insights from detrital zircon U-Pb age and Hf-O isotopes. Precambrian Res. 2015, 266, 165-178. [CrossRef]

80. Ma, X.; Yang, K.G.; Li, X.G.; Dai, C.G.; Zhang, H.; Zhou, Q.; McFarlane, C. Neoproterozoic Jiangnan Orogeny in Southeast Guizhou, South China: Evidence from U-Pb ages for Detrital Zircons from the Sibao Group and Xiajiang Group. Can. J. Earth Sci. 2016, 53, 219-230. [CrossRef]

81. Wang, H.; Wu, Y.B.; Gao, S.; Liu, X.C.; Gong, H.J.; Li, Q.L.; Li, X.H.; Yuan, H.L. Eclogite origin and timings in the North Qinling terrane, and their bearing on the amalgamation of the South and North China Blocks. J. Metamorph. Geol. 2011, 29, 1019-1031. [CrossRef]

82. Wang, Z.Z.; Guo, Y.; Yang, B.; Wang, S.W.; Sun, X.M.; Hou, L.; Zhou, B.G.; Liao, Z.W. Discovery of the 1.73 Ga Haizi Anorogenic Type Granite in the Western Margin of Yangtze Craton, and Its Geological Significance. Acta Geol. Sin. 2013, 87, 931-942.

83. Wang, D.B.; Yin, F.G.; Sun, Z.M.; Wang, L.Q.; Wang, B.D.; Liao, S.Y.; Tang, Y.; Ren, G.M. Zircon U-Pb age and Hf isotope of Paleoproterozoic mafic intrusion on the western margin of the Yangtze Block and their implications. Geol. Geol. Bull. China 2013, 32, 617-630.

84. Wang, S.W.; Liao, Z.W.; Sun, X.M.; Jiang, X.F.; Zhou, B.G.; Guo, Y.; Luo, M.J.; Zhu, H.P.; Ma, D. Geochemistry of Paleoproterozoic Diabases in the Dongchuan Copper deposit, Yunnan, SW China: Response to Breakup of the Columbia Supercontinent in the Southwestern Margin of Yangtze Block. Acta Geol. Sin. 2013, 87, 1834-1852.

85. Yang, H.; Liu, P.H.; Meng, E.; Wang, F.; Xiao, L.L.; Liu, C.H. Geochemistry and its tectonic implications of metabasite in the Dahongshan Group in Southwestern Yangtze block. Acta Petrol. Sin. 2014, 30, 3021-3033.

86. Belousova, E.; Griffin, W.L.; O’Reilly, S.Y.; Fisher, N. Igneous zircon: Trace element composition as an indicator of source rock type. Contrib. Min. Pet. 2002, 143, 602-622. [CrossRef]

87. Maas, R.; Kinny, P.D.; Williams, I.S.; Froude, D.O.; Compston, W. The Earth's oldest known crust: A geochronological and geochemical study of 3900-4200 Ma old detrital zircons from Mt. Narryer and Jack Hills, Western Australia. Geochim. Cosmochim. Acta 1992, 56, 1281-1300. [CrossRef]

88. Carley, T.L.; Miller, C.F.; Wooden, J.L.; Padilla, A.J.; Schmitt, A.K.; Economos, R.C.; Bindeman, L.N.; Jordan, B.T. Iceland is not a magmatic analog for the Hadean: Evidence from the zircon record. Earth Planet. Sci. Lett. 2014, 405, 85-97. [CrossRef]

89. Grimes, C.B.; Wooden, J.L.; Cheadle, M.J.; John, B.E. "Fingerprinting” tectono-magmatic provenance using trace elements in igneous zircon. Contrib. Min. Pet. 2015, 170, 46. [CrossRef]

90. Hawkesworth, C.J.; Kemp, A.I.S. Using hafnium and oxygen isotopes in zircons to unravel the record of crustal evolution. Chem. Geol. 2006, 226, 144-162. [CrossRef]

91. Yang, J.H.; Cawood, P.A.; Du, Y.S.; Huang, H.; Huang, H.W.; Tao, P. Large Igneous Province and magmatic arc sourced Permian-Triassic volcanogenic sediments in China. Sediment. Geol. 2012, 261-262, 120-131. [CrossRef]

92. Zhao, J.H.; Zhou, M.F.; Wu, Y.B.; Zheng, J.P.; Wang, W. Coupled evolution of Neoproterozoic arc mafic magmatism and mantle wedge in the western margin of the South China Craton. Contrib. Min. Pet. 2019, 174, 1-36. [CrossRef]

93. Roberts, N.M.W.; Slagstad, T. Continental growth and reworking on the edge of the Columbia and Rodinia super-continents: 1.86-0.9 Ga accretionary orogeny in southwest Fennoscandia. Int. Geol. Rev. 2015, 57, 1582-1606. [CrossRef]

94. Roy, A.; Sarkar, A.; Jeyakumar, S.; Aggrawal, S.K.; Ebihara, M. Mid-Proterozoic plume related thermal event in eastern Indian craton: Evidence from trace elements, REE geochemistry and $\mathrm{Sr}-\mathrm{Nd}$ isotope systematics of basic-ultrabasic intrusives from Dalma volcanic belt. Gondwana Res. 2002, 5, 133-146. [CrossRef]

95. Teixeira, W.; DAgrella-Filho, M.S.; Ernst, R.E.; Hamilton, M.A.; Girardi, V.A.V.; Mazzucchelli, M.; Bettencourt, J.S. U-Pb (ID-TIMS) baddeleyite ages and paleomagnetism of 1.79 and 1.59 Ga tholeiitic dyke swarms, and position of the Rio de la Plata Craton within the Columbia supercontinent. Lithos 2013, 174, 157-174. [CrossRef]

96. Silveira, E.M.; Söderlund, U.; Oliveira, E.P.; Ernst, R.E.; Menezes Leal, A.B. First precise U-Pb baddeleyite ages of 1500 Ma mafic dykes from the São Francisco Craton, Brazil, and tectonic implications. Lithos 2013, 174, 144-156. [CrossRef]

97. Rao, C.V.D.; Santosh, M. Continental arc magmatism in a Mesoproterozoic convergent margin: Petrological and geochemical constraints from the magmatic suite of Kondapalle along the eastern margin of the Indian plate. Tectonophysics 2011, 510, 151-171. [CrossRef]

98. Rao, C.V.D.; Santosh, M.; Zhang, Z.M.; Tsunogae, T. Mesoproterozoic arc magmatism in SE India: Petrology, zircon U-Pb geochronology and Hf isotopes of the Bopudi felsic suite from Eastern Ghats Belt. J. Asian Earth Sci. 2013, 75, $183-201$.

99. Subramanyam, K.S.V.; Santosh, M.; Yang, Q.Y.; Zhang, Z.M.; Balaram, V.; Reddy, U.V.B. Mesoproterozoic island arc magmatism along the south-eastern margin of the Indian Plate: Evidence from geochemistry and zircon $\mathrm{U}-\mathrm{Pb}$ ages of mafic plutonic complexes. J. Asian Earth Sci. 2016, 30, 116-138. [CrossRef] 
100. Furlanetto, F.; Thorkelson, D.J.; Rainbird, R.H.; Davis, W.J.; Gibson, H.D.; Marshall, D.D. The Paleoproterozoic Wernecke Supergroup of Yukon, Canada: Relationships to orogeny in northwestern Laurentia and basins in North America, East Australia, and China. Gondwana Res. 2016, 39, 14-40. [CrossRef]

101. Morel, M.L.A.; Nebel, O.; Nebel-Jacobsen, Y.J.; Miller, J.S.; Vroon, P.Z. Hafnium isotope characterization of the GJ-1 zircon reference material by solution and laser-ablation MC-ICPMS. Chem. Geol. 2008, 255, 231-235. [CrossRef] 